\title{
14. LOW-TEMPERATURE ALTERATION OF VERY YOUNG BASALTS FROM ODP HOLE 648B: SEROCKI VOLCANO, MID-ATLANTIC RIDGE ${ }^{1}$
}

\author{
A. C. Adamson ${ }^{2}$ and H. G. Richards ${ }^{3}$
}

\begin{abstract}
Basalts in Hole $648 \mathrm{~B}$, located in the rift valley of the Mid-Atlantic Ridge at $23^{\circ} \mathrm{N}$ in crust estimated to be less than 100,000 years old, are mainly fresh, but small amounts of secondary phases are found on fracture surfaces and in alteration halos within the rocks. The halos are defined by dark bands 1-4 mm thick that have developed parallel to fracture surfaces or pillow margins and which in some cases have migrated some centimeters into the rock. The dark bands are the principal locus of secondary phases. The secondary phases are olive-green and yellow protoceladonites, of composition and structure intermediate between celadonite and iron-rich saponite, red (Mn-poor) to opaque (Mn-rich) iron oxyhydroxides, mixtures of protoceladonite and iron oxyhydroxide, and rare manganese oxides. These phases occur mainly as linings or fillings of open spaces in the basalt within the dark bands. Sulfides and intersertal glass are the only primary phases that can be seen to have been altered. Where dark bands have migrated into the rock, the rock behind the advancing band is almost devoid of secondary phases, implying redissolution. The potassium and magnesium in the secondary phases could have been supplied from ambient seawater. The aluminum in the protoceladonites must have been derived from local reaction of intergranular glass. The source of iron and silica could have been intergranular glass or low temperature mineralizing solutions of the type responsible for the formation of deposits of manganese oxides and iron oxyhydroxides and silicates on the seafloor.
\end{abstract}

\section{INTRODUCTION}

Ocean Drilling Program (ODP) Site 648 is located in the rift valley of the Mid-Atlantic Ridge about $70 \mathrm{~km}$ south of the Kane Fracture Zone. The site is in a shallow part of the inner rift valley, on the summit plateau of a small axial volcano (Serocki Volcano). The morphology of this volcano and the surrounding area is known in detail through Sea Beam maps (Detrick et al., 1984), SeaMARC I data (Detrick et al., 1985), a shipboard television/sonar survey (Shipboard Scientific Party, 1988), and an Alvin submersible dive (Karson et al. 1986 ; in press). The volcano is about $800 \mathrm{~m}$ in diameter and stands about $50 \mathrm{~m}$ above the rift valley floor. At the center is a caldera about $100 \mathrm{~m}$ in diameter and $60 \mathrm{~m}$ deep (Karson et al., in press). The summit plateau consists of pillow lavas and rare sheet flows with light to moderate sediment cover. A number of rift valley parallel fissures dissect the western side of the volcano. Site 648 is located on the eastern side of the volcano about halfway between the caldera and the eastern rim. Two holes were drilled at this site; Hole $648 \mathrm{~A}$ which penetrated $4.5 \mathrm{~m}$ below seafloor with negligible recovery, and Hole $648 \mathrm{~B}$ which penetrated $50.5 \mathrm{~m}$ below seafloor and recovered $11.35 \mathrm{~m}$ of basalt. Most of the basalts recovered represent cored rubble although a number of cores contain long pieces of massive basalt that may have been cored in situ. The age of the volcano is estimated to be no more than a few tens of thousands of years (Shipboard Scientific Party, 1988).

The upper $30 \mathrm{~m}$ of the volcano is composed of aphyric to sparsely olivine-plagioclase phyric basalts with $<1 \%$ vesicles. These lavas are inferred to be pillowed and are underlain by a 3 -m-thick unit of sparsely olivine-plagioclase phyric basalt

\footnotetext{
${ }^{1}$ Detrick, R., Honnorez, J., Bryan, W. B., Juteau, T., et al., 1990. Proc. ODP, Sci. Results, 106/109: College Station, TX (Ocean Drilling Program).

${ }^{2}$ Ocean Drilling Program, Texas A\&M University, College Station, TX 77843.

${ }^{3}$ Camborne School of Mines Geothermal Energy Project, Rosemanowes Quarry, Herniss, Penryn, Cornwall TR10 9DU, United Kingdom.
}

with up to $10 \%$ vesicles, which grades into a 17.5 -m-thick unit composed of massive sparsely olivine-plagioclase phyric basalt with $<1 \%$ vesicles. The Shipboard Scientific Party (1988) interpret this sequence as representing a ponded lava with a vesicular top, overlain by later erupted pillow basalts.

The rocks recovered from Hole $648 \mathrm{~B}$ are predominantly fresh, but wherever natural fractures are present within or partially bounding the samples, such fractures are coated with secondary phases, and halos of secondary phases are developed within the rock. These phenomena record the earliest stage of the complex series of low temperature water-rock interactions involved in the aging of the upper oceanic crust. Hole 648B represents one of only a few cored sections showing such alteration without later overprinting. Other examples are described from Deep Sea Drilling Project (DSDP) Sites 424 and 425 (Fodor et al., 1980), and Sites 506, 507, and 508 (Laverne and Vivier, 1983; Schrader and Stow, 1983), at the Galapagos Spreading Center.

This paper documents the petrography and geochemistry of these secondary phases, and discusses whether they formed by the alteration of the basalts in which they occur, or by precipitation from externally-derived fluids, or by a combination of both processes.

\section{LOW TEMPERATURE ALTERATION OF OCEANIC BASALTS: AN OVERVIEW}

Basalts in the upper part of old oceanic crust show variable effects of alteration by seawater and/or chemically modified seawater and/or chemically modified seawater heated to temperatures up to about $100^{\circ} \mathrm{C}$. These effects have been referred to as brownstone facies alteration (Cann, 1979), as low temperature alteration (e.g., Honnorez, 1981), as low temperature oceanic alteration (Laverne, 1987), or as seafloor weathering, although Gillis and Robinson (1988) consider that this last term should be reserved for oxidative alteration by cold seawater. Characteristic minerals produced by low temperature alteration include smectite, celadonite, K-rich phillipsite, and $\mathrm{Na}$,Ca-zeolites (Cann, 1979; Honnorez, 1981; Gillis and Robinson, 1988). 
Bass (1976) presented the first detailed mineralogical investigation of basalts affected by low temperature alteration, using samples from DSDP Leg 34 . He proposed a four-stage process of alteration consisting of late magmatic-deuteric alteration, seawater or pre-burial alteration, post-burial nonoxidizing or limited oxidation alteration, and final post-burial oxidizing alteration. Similar stages of low temperature alteration have been recognized by other workers (Böhlke et al., 1980; Natland and Mahoney, 1981; Honnorez et al., 1983a), either occurring in the same order, or with oxidizing and non-oxidizing alteration stages reversed, suggesting that the sequence of alteration in the oceanic crust is highly complex and locally variable. The first stage of low temperature alteration, the formation of black halos by a process called low temperature mixed oxidizing alteration, so termed because the fluids involved are considered to be a mixture of cold sea water and hydrothermal fluids (Laverne 1987), have been described by Fodor et al. (1980), Laverne and Vivier (1983), Schrader and Stow (1983), and Laverne, from several DSDP holes, as well as at Hole 648B. The effects of localized oxidizing alteration forming red, orange, and yellow alteration halos adjacent to veins and fractures in the basalts have been described from a number of DSDP sites (e.g., Bass, 1976; Böhlke et al., 1980; Honnorez et al., 1983a; and Adamson, 1984).

Investigations by Kempe (1974), Bass (1976), Andrews (1977), Robinson et al. (1977), Scarfe and Smith (1977), Buckley et al. (1978), Pritchard (1979a, b), Andrews (1980), Natland and Mahoney (1981), Alt and Honnorez (1984), Donnelly et al. (1979), Honnorez et al. (1983a), and Adamson (1984) have shown potassium-rich dioctahedral mica as the most common clay mineral formed under oxidizing conditions at low temperatures (brownstone alteration). This resembles a celadonite in composition, although showing no true illite X-ray diffraction pattern. Donnelly et al. (1979) introduced the term "protoceladonite"' to describe this mineral, a term which has been used subsequently by Pritchard (1979a, b), Mevel (1979), Natland and Mahoney (1981), and Adamson (1984). Under non-oxidizing conditions a trioctahedral saponite forms (Banks, 1972; Melson and Thompson, 1973; Bass, 1976; Andrews, 1977, 1980; Seyfried et al., 1978; Scheidegger and Stakes, 1977; Böhlke et al., 1980; Stakes and Scheidegger, 1981). The saponites are often iron-rich and have been artificially reproduced under experimental conditions reacting basalt and seawater (Bischoff and Dickson, 1975; Hajash, 1975). Mixtures between celadonite (protoceladonite) and saponite minerals have been reported by a number of investigators (e.g., Andrews, 1980; Robinson et al., 1977; Natland and Mahoney, 1981; Adamson, 1984).

The chemical exchange between basalts and seawater during low temperature alteration has been summarized by Scott and Hajash (1976), who noted that water, ferric iron, potassium, rubidium, cesium, and uranium increase markedly, with a slight increase in total iron, boron, cerium, strontium, vanadium, chromium, and lead. Titanium and phosphorus are considered to be little affected by low temperature alteration (Cann, 1970; Robinson et al., 1977; Pritchard, 1979a), being merely redistributed into different phases. An extensive investigation of DSDP basalts by Thompson (1973) showed that silica, magnesium, and calcium are the principal elements removed from basalts, with seawater potassium added to them; alumina, total iron, and manganese are lost to a lesser extent. These findings have been generally confirmed by later investigations (Shido et al., 1974; Aumento et al., 1976; Bass, 1976; Pritchard, 1979a, b; Pritchard et al., 1979; Scarfe and Smith, 1977; Donnelly et al., 1979; Honnorez, 1981; Laverne and Vivier, 1983; Gillis and Robinson, 1988). Chemical budgets are discussed by Böhlke et al. (1980).

\section{ALTERATION PETROGRAPHY}

\section{Macroscopic features}

Although the majority of rocks recovered from Hole 648B are fresh, some samples have well-defined alteration halos developed parallel to fractures. In many cases these fractures have been split apart and now form the edges of samples. The fractures were filled or lined with secondary minerals which remain as coatings on the fracture surfaces.

Two types of alteration halo were identified by the Shipboard Scientific Party (1988):

Type 1: 1-4-mm-thick dark bands are developed parallel to and adjacent to the fracture surfaces, which are coated or filled with secondary phases. Any other fracture surfaces or vesicles or vugs the bands encounter are also coated with secondary phases.

Type 2: 1-4-mm-thick dark bands are developed within the rock, usually subparallel to a fracture that is coated with secondary phases. A lighter zone, referred to as a "light front" by Böhlke et al. (1980), extends from the fracture surface to the edge of the dark band. The lighter zone varies in thickness from a few millimeters to several centimeters, and may contain sparse flecks of yellow to orange alteration minerals. Dark bands of Type 2 halos are identical to the Type 1 halos. Some rock samples have a Type 1 band that grades into a Type 2 band indicating that Type 2 halos can develop by "penetration" of Type 1 dark bands into the rock, although the halos may have developed in situ by double diffusion precipitation (Honnorez, pers. comm., 1989). Type 2 halos are also occasionally developed subparallel to glassy pillow margins, up to $3.5 \mathrm{~cm}$ into the rock. In such cases, however, the outermost rims of the pillows have been abraded during drilling, and so it is not possible to say whether the outer rims were coated with secondary phases, as is the case with the fracture surfaces adjacent to Type 2 halos.

The appearances of the various types of halo in the core are illustrated in the Site 648 Report (Shipboard Scientific Party, 1988).

\section{Thin section petrography}

The Shipboard Scientific Party (1988) identified five petrographic types of secondary phase. These are as follows:

1. Olive-green clay has a low refractive index and is optically virtually isotropic. It can contain browner or greener layers when in vesicles.

2. Yellow clay has a low to moderate birefringence which increases from greenish yellow to orangish yellow. It can form linings up to $80 \mu \mathrm{m}$ in vesicles, where it exhibits a strongly parallel to locally radiate growth structure. In hand specimen, the vesicle lining yellow clay appears pale blue when viewed against the dark, often glassy basalt forming the vesicle walls.

3. Orange-red clay has moderate birefringence and a higher refractive index than the other clays. It probably represents a mixture of clay and iron oxyhydroxide.

4. Red iron oxyhydroxide is isotropic, has a high refractive index, and has a moderate reflectivity.

5. Opaque iron oxyhydroxide.

The red opaque iron oxyhydroxides were identified by microprobe analysis. Although this list was based upon detailed examination of only 4 thin sections, we did not find any additional phases in our subsequent study of a further 20 sections, apart from rare manganese-rich opaque oxyhydroxides, distinguishable only by microprobe analysis. Our thin section studies also confirmed that the paragenetic relationships described by the Shipboard Scientific Party (1988) have general applicability to Hole 648B. 
The secondary phases occur in a variety of open space filling sites, including fractures, vesicles, micromiarolitic cavities, and rare larger vugs. Fractures may be lined or completely sealed. Sealed fractures within the sample are generally less than $50 \mu \mathrm{m}$ in original aperture. The lining phases may be any of the five phases listed above, and transitions from one type of lining to another occur along the length of a fracture (over a distance of a few millimeters). Study of five thin sections of fresh basalt impregnated with a blue-dyed resin showed that micromiarolitic voids are widespread, appearing as irregular patches of blue up to $1 \times 2 \mathrm{~mm}$ in size, into which project euhedral plagioclase and/or clinopyroxene. The larger voids may have multiple linings, usually iron oxyhydroxides overgrowing yellow clay. Micromiarolitic voids show a complete range of sizes down to the submicroscopic and the smaller voids may be completely filled, most often with yellow or olive-green clay. Vesicles may also show multiple linings, as illustrated in the Site 648 Report (Shipboard Scientific Party, 1988). In both vesicles and micromiarolitic cavities, the optical characteristics of a given layer of a lining is always uniform, in contrast to the variations seen in fracture linings and fillings.

In all open space filling sites, linings of olive-green or yellow clay never exceed about $80 \mu \mathrm{m}$ in thickness. The thickest deposits of secondary phases observed were asymmetric partial vesicle fillings of iron oxyhydroxide up to 700 $\mu \mathrm{m}$ in apparent thickness.

Evidence for replacement of primary phases is scarce in Hole 648B basalts. In the coarser basalts deeper in the hole, it can be seen that the relatively large primary sulfide globules may be progressively replaced by red iron oxyhydroxide in the light zones of Type 2 halos, via aggregates of both primary and secondary phases having a speckled appearance in reflected light. In the dark bands of these halos, sulfides can also be incipiently altered. Sulfide alteration is more difficult to demonstrate in the fine grained basalts of the pillowed unit, but may reasonably be inferred. The coarser basalts also contain intersertal patches of pale brownish translucent glass, often with a vermiform texture. These glass patches may show partial alteration, usually to yellow clay, forming patches about $10-20 \mu \mathrm{m}$ across, with cuspate boundaries with the fresh glass. This is the only evidence seen for replacement of a primary aluminosilicate phase by secondary phases. In the fine grained basalts, interstitial glass is not optically distinguishable. This does not mean that it is absent, as it may occur as submicroscopic intergranular films.

Where a section is cut approximately normal to a natural fracture surface and associated halo, a systematic distribution of alteration minerals with respect to the halo is apparent. The olive-green clay occurs at the fresh rock-halo boundary. Further away from the boundary but still within the dark zone, the clay becomes increasingly yellow and birefringent, and more abundant. The clay lining vesicles is the same color as the clay in the surrounding rock matrix. The orange-red clays and red iron oxyhydroxides appear further from the fresh rock-halo boundary and can overlap with the yellow claybearing zone, but it is usually the case that the red iron oxyhydroxides are paragenetically later (e.g., in vesicle linings) than the yellow clays. A similar distribution has been observed at DSDP Sites 506, 507, and 508 in the Galapagos Spreading Center (Laverne and Vivier, 1983).

In the light zones of Type 2 halos, rare orange-red clays and iron oxyhydroxides are the only secondary phases. Within these zones, all primary sulfides have been altered to red iron oxyhydroxides, and where intersertal glass is present, it gives a rougher polished surface than in the fresh rock, implying the dissolution of formerly present secondary phases. Micromiarolitic cavities, though partly filled with secondary phases in the adjacent dark band zones, are mainly void in the light zones, although this does not necessarily imply that these cavities were filled in the first stage. Thus it appears that the progress of Type 1 halos into the rock to form Type 2 halos involved redissolution of most of the secondary phases from the zones through which the dark bands have passed.

\section{CHEMISTRY AND STRUCTURE OF SECONDARY PHASES}

Twenty basalt samples from Hole 648B, containing both types of alteration halo (Table 1), were studied in thin section and analyzed by electron microprobe; of these, eight were further analyzed by X-ray diffraction.

\section{Analytical Techniques}

Chemical analyses of secondary minerals were determined by electron microprobe analysis. Two instruments were used; a JEOL model JAX-733 "Superprobe"' at Southern Methodist University, Dallas, TX, and a Cambridge Instruments Geoscan EDS at Manchester University, U.K. In the case of the former, normal operating conditions were $15 \mathrm{kV}$ excitation voltage, $20 \mathrm{nA}$ beam current, and $30 \mathrm{~s}$ counting time; beam diameters were 10 or $20 \mu \mathrm{m}$. Elements analyzed for were sodium, magnesium, aluminum, silicon, sulfur, chlorine, potassium, calcium, titanium, chromium, manganese, iron, and nickel. In the case of the Geoscan microprobe, normal operating conditions were $15 \mathrm{kV}$ excitation voltage, $3 \mathrm{nA}$ beam current, and $100 \mathrm{~s}$ counting time; beam diameters were $20 \mu \mathrm{m}$. Elements analyzed for were sodium, magnesium, aluminum, silicon, potassium, calcium, titanium, manganese, iron, and barium.

X-ray diffractograms were obtained using a Rigaku model D-2005 Miniflex X-ray diffractometer and $\mathrm{Cu} \mathrm{K} \alpha$ radiation. Samples were scanned in $0.02^{\circ} 2 \theta$ steps from $2^{\circ}$ to $5^{\circ} 2 \theta$. Halo material was selectively removed by diamond saw from eight samples and ground under water to a fine slurry in an agate pestle and mortar. A small amount of slurry was then transferred to a glass slide and allowed to air-dry before being X-rayed.

Table 1. Details of basalt samples from Hole 648B used in this study.

\begin{tabular}{lcrcl}
\hline Core & $\begin{array}{c}\text { Interval } \\
(\mathrm{cm})\end{array}$ & Piece & $\begin{array}{c}\text { Reference } \\
\text { number }\end{array}$ & Alteration halo type \\
\hline IR-1 & $32-22$ & 6 & 1 & $\begin{array}{c}\text { I (plus Type I halo } \\
\text { surrounding } 7 \times\end{array}$ \\
& & & & 4 mm vug) \\
IR-2 & $78-81$ & 14 & 2 & 1 \\
& $29-34$ & 5 & 3 & 2 \\
1R-3 & $51-59$ & 9 & 4 & 2 \\
& $0-6$ & 1 & 5 & 1 \\
4R-1 & $36-39$ & 8 & 6 & 2 \\
& $10-14$ & 3 & 7 & 1 and 2 \\
6R-1 & $22-27$ & 5 & 8 & 2 (double halo) \\
8 R-1 & $85-89$ & 17 & 9 & 1 \\
& $7-9$ & 2 & 10 & 2 \\
9R-1 & $59-61$ & 8 & 11 & 1 and 2 \\
10R-1 & $68-71$ & 10 & 12 & 1 \\
15R-1 & $14-5$ & 1 & 13 & - \\
16R-1 & $0-5$ & 143 & 14 & 2 \\
& $2-5$ & 1 & 15 & 2 \\
18R-1 & $29-32$ & 3 & 16 & 2 \\
& $0-2$ & $1 \mathrm{~A}$ & 17 & 1 and 2 \\
& $0-2$ & $1 \mathrm{~A}$ & 19 & 2 \\
& $17-21$ & 2 & 20 & 1 \\
\hline
\end{tabular}




\section{Mineral chemistry presentation}

Clay mineral analyses are presented in this paper using a three-dimensional graphical method that enables the rapid categorization of large numbers of analyses of unknown clay phases (Adamson, 1983, 1984). Alteration products are considered to be clay minerals with a 2:1 layered phyllosilicate structure (Bailey, 1980), and analyses are recalculated on the basis of 22 oxygens. Such analyses can be plotted on axes of the inter-layer charge $(2 x \mathrm{Ca}+\mathrm{Na}+\mathrm{K})$ and total $\left(\mathrm{Al}+\mathrm{Fe}^{3+}\right)$, which enable various layer silicate type compositions to be plotted. It should be noted that in the case of the secondary phases in Hole $648 \mathrm{~B}, \mathrm{Al}$ is very much subordinate to $\mathrm{Fe}^{3+}$. The introduction of a third axis, measuring the dioctahedral, trioctahedral, or intermediate nature of analyses, subdivides clusters into linear trends along which systematic changes in substitution and chemistry can be observed. This third axis comprises the sum of $\mathrm{Si}+\mathrm{Al}+\mathrm{Mg}+\mathrm{Fe}(\mathrm{T})$ (SAMF), which takes a value of 14 for trioctahedral 2:1 layered clays and 12 for dioctahedral 2:1 layered clays.

Mineral analysis with the electron microprobe determines elemental abundances, but does not determine the oxidation states of elements, of which that of iron is the most important. In the clay minerals generally, there is a wide and continuous variation in oxidation state, and different assumptions about the degree of oxidation of iron can affect the structural and chemical interpretation of analyses. If the estimated oxidation ratio of iron, $\mathrm{Fe}^{3+} /\left(\mathrm{Fe}^{2+}+\mathrm{Fe}^{3+}\right)$, is increased, the iron in the analysis is transferred from trioc- tahedral to dioctahedral or tetrahedral sites, and estimated total $\left(\mathrm{Al}+\mathrm{Fe}^{3+}\right)$ increases. The effect of adding more oxygen to the formula also reduces the number of cations per 22 oxygens, and inter-layer charge and SAMF are reduced accordingly (Adamson, 1984).

Since the oxidation state of iron is important for interpreting clay minerals using this method, an accurate estimate of oxidation ratio must be made. Not all clay analyses from a given hole will have the same oxidation ratio. However, available celadonite and potassium-rich clay mineral (protoceladonite) analyses with wet chemical determinations of oxidation ratios show consistent oxidation ratios of $0.8 \pm 0.01$ (Table 2). Since the main clay phase in Hole $648 \mathrm{~B}$ is protoceladonite (as discussed below), we have applied an oxidation ratio correction of 0.8 to our analyses to give a best estimate of the in situ elemental state of these clay minerals. We suspect that the oxidation ratio in the iron oxyhydroxides is even higher, but to enable a consistent method of data presentation and interpretation, we have applied a ratio of 0.8 to these phases as well. Since all the secondary phases in Hole 648B are thus initially highly oxidized, any post-sampling oxidation of iron should have been negligible.

\section{Chemical analysis results}

About 400 analyses of secondary phases were collected as a series of transects across alteration halos. All layered features, such as the variegated linings to vesicles, were probed in order to obtain representative analyses of each color and/or mineral type present.

Table 2. Representative celadonite and potassium-rich clay mineral (protoceladonite) analyses from oceanic basalts and other localities.

\begin{tabular}{|c|c|c|c|c|c|c|c|c|c|c|c|c|c|c|}
\hline & $\begin{array}{c}\mathrm{a} \\
170\end{array}$ & $\begin{array}{c}\mathrm{b} \\
332 \mathrm{~B}\end{array}$ & $\begin{array}{c}\mathrm{c} \\
332 \mathrm{~B}\end{array}$ & $\begin{array}{c}d \\
417 \mathrm{~A}\end{array}$ & $\begin{array}{c}\mathrm{e} \\
417 \mathrm{~A}\end{array}$ & $\begin{array}{c}\mathrm{f} \\
458\end{array}$ & $\underset{501}{g}$ & $\begin{array}{c}\mathrm{h} \\
504 \mathrm{~A}\end{array}$ & $\stackrel{\mathrm{i}}{504 \mathrm{~B}}$ & $\underset{504 \mathrm{~B}}{\mathrm{j}}$ & $\begin{array}{c}k \\
\text { CY-la }\end{array}$ & $\stackrel{1}{\text { OFB }}$ & $\mathrm{m}$ & $\mathrm{n}$ \\
\hline $\mathrm{SiO}_{2}$ & 54.84 & 47.17 & 53.29 & 48.72 & 51.90 & 45.30 & 47.05 & 51.63 & 51.82 & 51.80 & 55.85 & 53.58 & 53.40 & 55.61 \\
\hline $\mathrm{TiO}_{2}$ & - & - & - & - & - & - & 0.00 & 0.00 & 0.00 & 0.00 & 0.16 & 0.20 & 0.04 & 0.79 \\
\hline $\mathrm{Al}_{2} \mathrm{O}_{3}$ & 1.69 & 1.75 & 0.28 & 4.49 & 2.27 & 3.18 & 2.39 & 2.19 & 1.75 & 3.69 & 2.32 & 5.28 & 2.51 & - \\
\hline $\mathrm{Fe}_{2} \mathrm{O}_{3}$ & 17.05 & 24.75 & 23.69 & 20.79 & 20.95 & 10.49 & 26.07 & 25.08 & 19.03 & 23.46 & 15.73 & 14.61 & 15.88 & 17.19 \\
\hline $\mathrm{FeO}{ }^{3}$ & 3.84 & 5.58 & 5.34 & 4.68 & 4.72 & 2.36 & 5.87 & 5.65 & 4.29 & 5.29 & 3.54 & 3.37 & 3.53 & 4.02 \\
\hline $\mathrm{FeO}(\mathrm{T})$ & 19.21 & 27.88 & 26.69 & 23.42 & 23.60 & 11.82 & 29.37 & 28.26 & 21.44 & 26.43 & 17.72 & 16.52 & 17.82 & 19.49 \\
\hline $\mathrm{MgO}$ & 6.98 & 4.33 & 6.11 & 5.03 & 5.08 & 5.55 & 4.05 & 3.37 & 9.04 & 4.63 & 6.18 & 6.35 & 6.45 & 7.26 \\
\hline $\mathrm{CaO}$ & 0.07 & 0.28 & 0.15 & 0.40 & 0.51 & 0.22 & 0.60 & 0.76 & 0.84 & 1.63 & 0.00 & 0.68 & 0.07 & 0.21 \\
\hline $\mathrm{Na}_{2} \mathrm{O}$ & 0.15 & 0.38 & 0.34 & 0.11 & 0.03 & 0.14 & 0.00 & 0.00 & 0.09 & 0.79 & 0.10 & 0.31 & 0.05 & 0.19 \\
\hline $\mathrm{K}_{2} \mathrm{O}$ & 8.93 & 6.49 & 7.07 & 7.12 & 7.86 & 6.35 & 6.60 & 6.78 & 6.48 & 6.55 & 9.44 & 7.69 & 10.28 & 10.03 \\
\hline Total & 93.55 & 90.72 & 96.27 & 91.34 & 93.32 & 73.60 & 92.63 & 95.47 & 93.34 & 97.84 & 93.32 & 91.07 & 92.21 & 100.27 \\
\hline $\mathrm{Si}$ & 7.97 & 7.34 & 7.69 & 7.37 & 7.69 & 8.12 & 7.21 & 7.56 & 7.58 & 7.37 & 8.08 & 7.74 & 7.91 & 7.99 \\
\hline $\mathrm{Al}$ & 0.03 & 0.32 & 0.05 & 0.63 & 0.31 & 0.00 & 0.43 & 0.43 & 0.38 & 0.30 & 0.00 & 0.26 & 0.09 & 0.01 \\
\hline Al & 0.26 & 0.00 & 0.00 & 0.18 & 0.08 & 0.67 & 0.00 & 0.00 & 0.00 & 0.00 & 0.40 & 0.65 & 0.35 & 0.13 \\
\hline $\mathrm{Ti}$ & - & - & - & - & - & - & 0.00 & 0.00 & 0.00 & 0.00 & 0.02 & 0.02 & 0.00 & - \\
\hline $\mathrm{Fe} 3$ & 1.86 & 2.90 & 2.57 & 2.37 & 2.33 & 1.42 & 3.01 & 2.76 & 2.09 & 2.51 & 1.71 & 1.62 & 1.77 & 1.86 \\
\hline $\mathrm{Fe} 2$ & 0.47 & 0.73 & 0.64 & 0.59 & 0.58 & 0.35 & 0.75 & 0.69 & 0.52 & 0.63 & 0.43 & 0.42 & 0.44 & 0.48 \\
\hline $\mathrm{Mg}$ & 0.51 & 1.00 & 1.31 & 1.13 & 1.12 & 1.48 & 0.92 & 0.73 & 1.97 & 0.98 & 1.33 & 1.39 & 1.43 & 1.55 \\
\hline $\mathrm{Ca}$ & 0.01 & 0.05 & 0.02 & 0.06 & 0.08 & 0.04 & 0.10 & 0.12 & 0.13 & 0.25 & 0.00 & 0.11 & 0.01 & 0.03 \\
\hline $\mathrm{Na}$ & 0.04 & 0.11 & 0.10 & 0.03 & 0.01 & 0.05 & 0.00 & 0.00 & 0.03 & 0.22 & 0.03 & 0.09 & 0.01 & 0.05 \\
\hline $\mathrm{K}$ & 1.65 & 1.29 & 1.30 & 1.38 & 1.48 & 1.45 & 1.29 & 1.27 & 1.21 & 1.19 & 1.74 & 1.44 & 1.94 & 1.84 \\
\hline SAMF & 12.10 & 12.30 & 12.27 & 12.27 & 12.12 & 12.04 & 12.33 & 12.12 & 12.47 & 12.11 & 11.95 & 12.08 & 11.99 & 12.02 \\
\hline $\mathrm{Al}+\mathrm{Fe}^{3+}$ & 2.15 & 3.22 & 2.62 & 3.17 & 2.73 & 2.09 & 3.44 & 3.14 & 2.40 & 3.13 & 2.11 & 2.53 & 2.21 & 2.00 \\
\hline$(\mathrm{EX}+)$ & 1.72 & 1.50 & 1.44 & 1.54 & 1.66 & 1.59 & 1.49 & 1.50 & 1.50 & 1.90 & 1.77 & 1.64 & 1.96 & 1.93 \\
\hline OR & $0.8^{*}$ & 0.8 & 0.8 & 0.8 & 0.8 & 0.8 & 0.8 & 0.8 & 0.8 & 0.8 & 0.8 & $0.7^{*}$ & $0.80^{*}$ & $0.79^{*}$ \\
\hline
\end{tabular}

Structural formulas calculated on the basis of 22 oxygens.

"Denotes oxidation ratio determined by wet chemical analysis. Other analyses recalculated with oxidation ratio of 0.8 . $(\mathrm{EX}+)$ is inter-layer charge. OR is oxidation ratio $\mathrm{Fe}^{3+} /\left(\mathrm{Fe}^{3+}+\mathrm{Fe}^{2+}\right)$. Sources of data: a, l, and $\mathrm{m}$, Buckley et al. (1978); b, Andrews (1977, Table 3); c, Andrews (1980, Table 4); d, Alt and Honnorez (1984. Table 1); e, Donnelly et al. (1979. Table 1); f, Natland and Mahoney (1981, Table 2); $\mathrm{g}$ and h, Adamson (1984, Table C3.4); i, Honnorez et al. (1983, Table 3B); j, Pertsev and Boronikhin (1983, Table 4); k, Gillis (1986. Table IV-3); $\mathrm{m}$ and $\mathrm{n}$, Hendricks and Ross (1941), a through $\mathrm{j}$ are from the indicated DSDP holes. $\mathrm{k}$ is from Hole CY-1a in Troodos ophiolite. I is from an ocean floor basalt sample. $\mathrm{m}$ and $\mathrm{n}$ are from non-oceanic localities. 

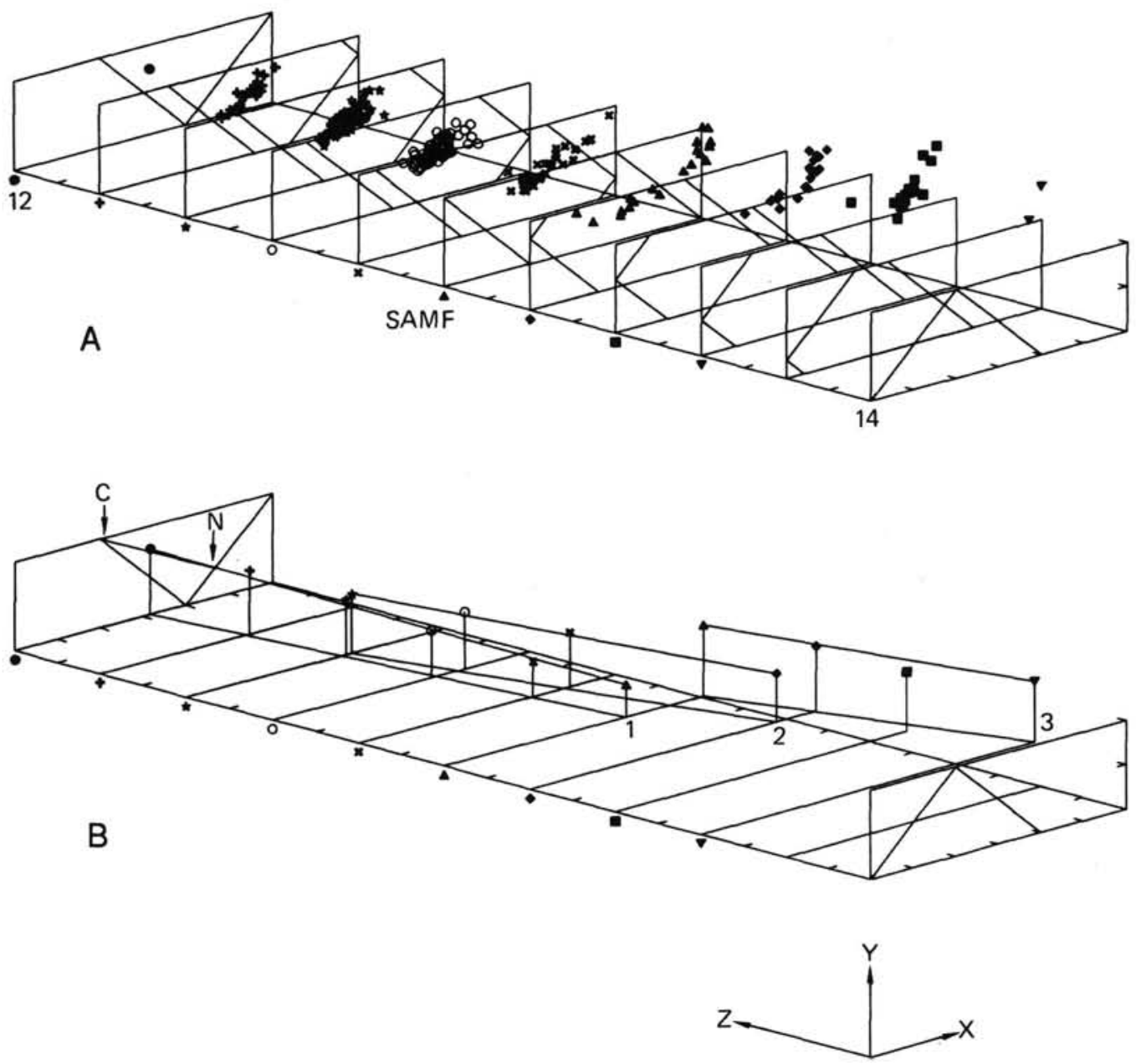

Figure 1. Analyses of secondary phases from Hole 648B, recalculated to 22 oxygens, plotted with respect to total $\left(\mathrm{Al}+\mathrm{Fe}^{3+}\right.$ ) from 0 to 6 (X-axis), inter-layer charge from 0 to 2 (Y-axis) and SAMF from 14 to 12 (Z-axis). A. Plot of all analyses, with projection on to nearest plane with SAMF equal to an exact multiple of 0.2 . See text for discussion. The data points on each plane have a separate symbol which is indicated on the SAMF axis. B. Summary of chemical trends in the data: (1) potassium-rich analyses, (2) potassium-iron-rich analyses, (3) iron-rich analyses. $\mathrm{C}$ and $\mathrm{N}$ show the positions of ideal celadonite and nontronite. The diagonal lines delineate the field of 2:1 layered clay minerals. Note that some high SAMF analyses plot outside the coordinate axes.

Figure 1A shows all analyses from Hole 648B plotted with respect to the three-dimensional axes described above. As SAMF values increase from 12 , the clusters evident in this figure begin to diverge, with a distinct high total $\left(\mathrm{Al}+\mathrm{Fe}^{3+}\right)$ trend developing. If each plane is plotted on a larger scale (not shown here), a distinct group of analyses with less high total $\left(\mathrm{Al}+\mathrm{Fe}^{3+}\right)$ is evident between SAMF values of 12.4 and 13.2. This can be seen in Figure 1A where the clusters at SAMF 12.6 (open circles) and 12.8 (crosses) show a distinct elongation of their respective clusters, intermediate between the extremely high total $\left(\mathrm{Al}+\mathrm{Fe}^{3+}\right)$ groups of SAMF $>13.0$, and the low total $\left(\mathrm{AI}+\mathrm{Fe}^{3+}\right)$ groups of SAMF $<13.0$.

To clarify the trends in the data, the average compositions of all clusters distinguishable in Figure 1A are plotted on the same axes in Figure 1B. Three trends may be recognized, as shown in Figure 1B:

1. Tight clusters of points in the SAMF range 12-13,

2. Clusters of intermediate total $\left(\mathrm{Al}+\mathrm{Fe}^{3+}\right)$ in the SAMF range 12.4-13.2, identified using more detailed plots as discussed above,

3. Diffuse clusters with high total $\left(\mathrm{Al}+\mathrm{Fe}^{3+}\right)$ in the SAMF range 12.6-13.8.
In Figure 2, Trend 1 is shown as linking the lowest SAMF analysis (filled circle) to the center of the low total $\left(\mathrm{Al}+\mathrm{Fe}^{3+}\right)$ group within the SAMF = 13 division (filled triangle), and passes close to the centers of the groups of SAMF $=12.2$ (cross), SAMF $=12.4$ (star), SAMF $=12.6$ (open circle), and SAMF $=$ 12.8 (filled X). Trends 2 and 3 similarly link the centers of other clusters, indicated by large symbols. The same data presentation methods used in Figure 2 are employed in Figure 3, which used the coordinates SAMF and total $\left(\mathrm{Al}+\mathrm{Fe}^{3+}\right)$. The following sections discuss each compositional trend in turn, with reference to the diagrams described above.

\section{Trend 1 (potassium-rich analyses)}

Analyses belonging to Trend 1 have characteristically high potassium contents (up to $7 \mathrm{wt} . \% \mathrm{~K}_{2} \mathrm{O}$ ) that vary as a function of SAMF (i.e., as a function of dioctahedral-trioctahedral character). As can be seen in Table 3, as SAMF increases, $\mathrm{K}_{2} \mathrm{O}$ content decreases from about 7 wt. $\%$ at SAMF 12.2 to about 2 wt.\% at SAMF 13. The trend is well defined in Figure 1 ; the central part of each cluster, calculated by determining average values from constituent analyses, plots close to a straight line connecting the end-members at SAMF 12 and 13. 


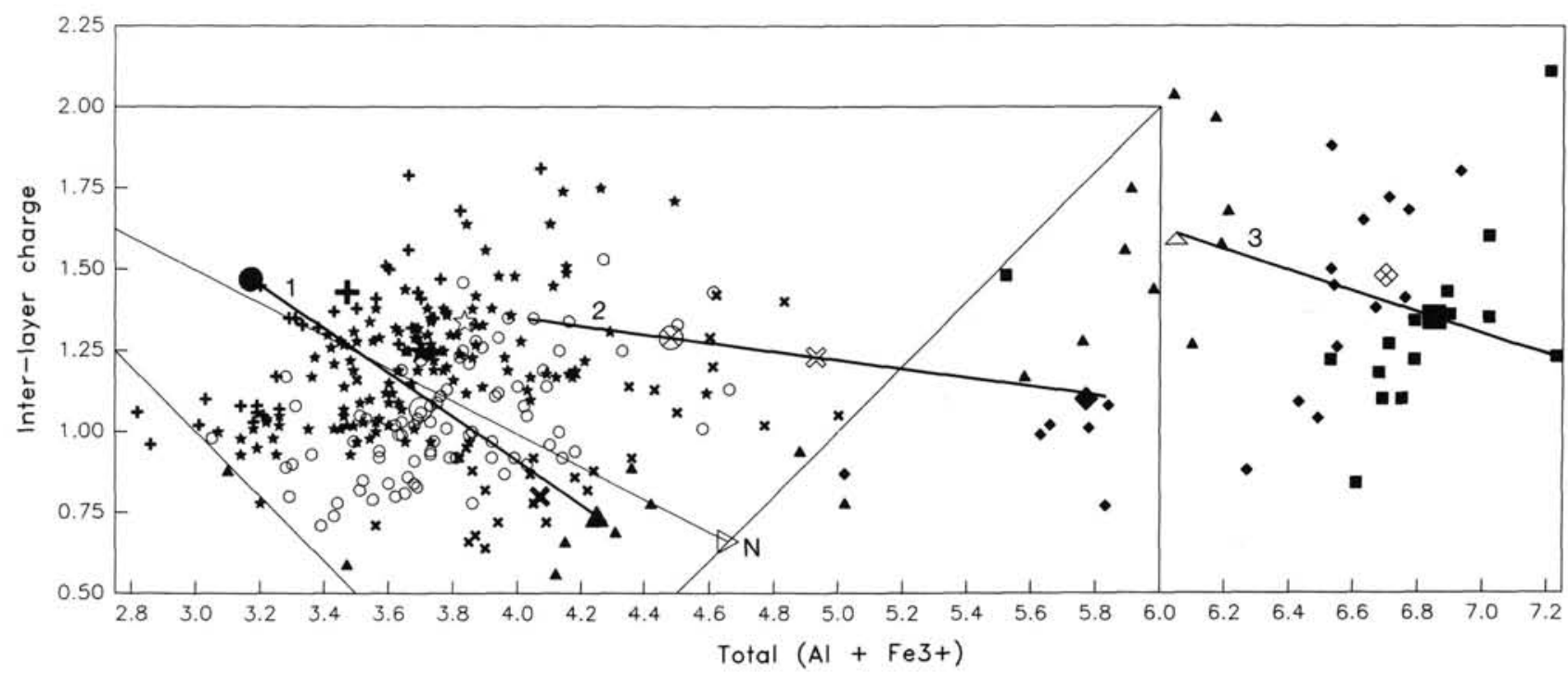

Figure 2. All Hole $648 \mathrm{~B}$ analyses plotted with respect to inter-layer charge and total $\left(\mathrm{Al}+\mathrm{Fe}^{3+}\right)$. Symbols and trend numbers as in Figure 1. Large symbols correspond to points plotted in Figure $1 \mathrm{~B}$ and represent the average composition of each cluster. Where a distinction has been drawn between high and less high total $\left(\mathrm{Al}+\mathrm{Fe}^{3+}\right)$ clusters within a SAMF division, the average of the former is indicated by a large open symbol of the same shape as the filled symbol used for the others. The large filled star is at approximately 3.7, 1.24. $\mathrm{N}$ is the position of ideal nontronite, from which a mixing line has been drawn toward ideal celadonite (off the diagram). The diagonal lines delineate the field of 2:1-layered clay minerals. The vertical and horizontal lines within the diagram indicate the boundar ${ }^{\circ} \mathrm{s}$ of the coordinate system used in Figure 1.

This is further illustrated in Figures 2 and 3. The majority of analyses fall between SAMF 12.1 and 12.9; a single analysis with extreme dioctahedral character plots at SAMF 12.07 (analysis 393 in Table 3). Inter-layer charge is dominated by potassium, and so it decreases with increasing SAMF, as does silica. Iron (and consequently total $\left(\mathrm{Al}+\mathrm{Fe}^{3+}\right)$ ) increases with increasing SAMF, as does magnesium. All other elements show limited variation. Compositional variations within the clusters are on the order of 0.7 atoms of inter-layer charge and 1 atom of total $\left(\mathrm{Al}+\mathrm{Fe}^{3+}\right)$.

The dioctahedral end-member of Trend 1 (filled circle in Figs. 1 and 2) lies on a line connecting celadonite and nontronite and may represent a mixture between these two minerals. Viewed in terms of clay formulas, analyses in Trend 1 show tetrahedral substitution increasing with increasing SAMF from about 0.5 to about 1.5 ; the octahedral totals increase likewise from about $4.5-5$ to $>6$ (Table 3 ). For comparison, ideal celadonite has zero tetrahedral substitution and an octahedral total of 4 , while nontronite has 0.7 tetrahedral substitution and an octahedral total of 4 . None of these analyses, therefore, represent pure dioctahedral clay minerals, but probably represent mixtures of a dioctahedral clay mineral and a trioctahedral end-member. The chemical evidence would suggest that the dioctahedral end-member is probably more celadonitic in composition than nontronitic, principally because of the high inter-layer

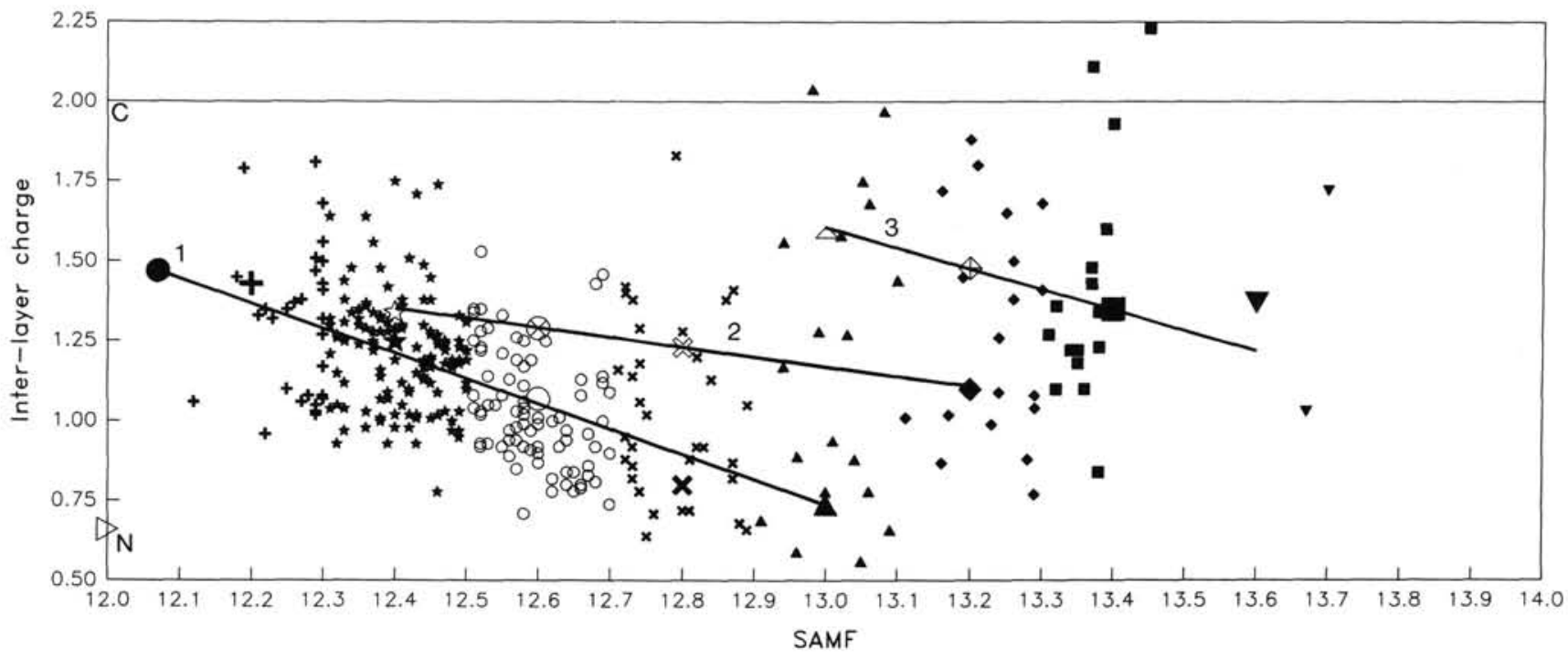

Figure 3. All Hole 648B analyses plotted with respect to inter-layer charge and SAMF. Symbols and trend numbers as in Figure 2. C $=$ celadonite. $\mathrm{N}=$ nontronite. 
charge of these analyses. Furthermore, the principal interlayer ions in nontronite are typically calcium and sodium, not potassium.

The nature of the trioctahedral end-member is more difficult to ascertain. If the trend was to be continued in Figure 1B to intersect the SAMF 14 plane, the point would be outside the triangle delineating trioctahedral 2:1 layered clay minerals. Adamson (1984) describes a similar trend in a study of samples from DSDP Hole 504B, but comprising dominantly trioctahedral-rich members. Although this trend and our Trend 1 from Hole 648B do not overlap, this may be a result of the different oxidation ratios applied to the analyses in each of the two cases $(0.3$ in the case of Hole $504 \mathrm{~B}, 0.8$ in the case of Hole 648B). Decreasing the oxidation ratio in the Hole $648 \mathrm{~B}$ analyses would move the analyses to higher values of SAMF, increase inter-layer charge, and lower the proportion of iron assigned to total ( $\mathrm{Al}$ $\left.+\mathrm{Fe}^{3+}\right)$. This could bring the two trends into line suggesting that the trioctahedral end-member to the Hole 648B trend is a saponite.

Trend 1 therefore represents a mixing line between a dioctahedral mineral of celadonitic composition and a trioctahedral saponite, with most analyses exhibiting intermediate characteristics. Similar analyses have been reported by many workers studying ocean floor basalts (e.g., Andrews, 1977, 1980; Buckley et al., 1978; Natland and Mahoney, 1981; Alt and Honnorez, 1984; Donnelly et al., 1979; Staudigel et al., 1981; Honnorez et al., 1983a; Laverne and Vivier, 1983; Pertsev and Boronikhin, 1983; Gillis 1986) and are listed in Table 2 and illustrated in Figure 4. As Figure 4 shows, analyses from Hole 648B tend to be more iron rich and lower in potassium than those reported elsewhere. It is also notable that many of the Hole $648 \mathrm{~B}$ analyses are very low in aluminum, often below $1 \mathrm{wt} . \% \mathrm{Al}_{2} \mathrm{O}_{3}$, and sometimes below $0.1 \%$.

Since there is a complete spectrum of chemical compositions between the end-members, some workers consider the potassium-rich phases to represent mechanical mixtures of saponite and celadonite (e.g., Andrews, 1980; Rusinov et al., 1979; Natland and Mahoney, 1981). Other workers, however, consider them to represent a transitional type of mineral between the end-members smectite and celadonite (e.g., Donnelly et al., 1979; Pritchard, 1979a, b) and use the term "protoceladonite"' to describe them. Donnelly et al. (1979) define protoceladonite as being a clay mineral with chemical properties comparable to those of the micas, but with no mica X-ray pattern. X-ray analysis of clay mineral samples from Hole $648 \mathrm{~B}$, discussed in detail later, exhibit no $10 \AA$ peak that would indicate a mica structure.

\section{Trend 2 (potassium-iron-rich analyses)}

Trend 2 is most clearly seen in Figure 1B and comprises a diffuse set of analyses that lies between Trends 1 and 3 . These analyses are distinguished from Trend 1 analyses with the same SAMF by their higher iron contents. They also have higher calcium contents (Table 4; analyses numbers 344-369), leading to high apparent inter-layer charges. The iron content of the analyses forming this trend increases slightly with increasing SAMF, whereas potassium decreases slightly. Trend 2 clearly diverges from Trend 1 at SAMF 12.6 (Fig. 1A) and continues through the elongate group of analyses comprising the SAMF division 12.7-12.9, toward a cluster at $\mathrm{SAMF}=13.2$, with a gap between SAMF $=12.9-13.1$. Analyses belonging to this trend are interpreted as mixtures between the protoceladonites of Trend 1 and the distinctly iron-rich phases comprising Trend 3.

\section{Trend 3 (iron-rich analyses)}

This trend is composed of 45 analyses with SAMF between 13 and 13.7 (Figs. 1 and 3). They are characterized by high iron contents that increase with increasing SAMF from about $45-50$ wt. $\% \mathrm{FeO}(\mathrm{T})$ at SAMF 13 to $55-60 \mathrm{wt} . \%$ at SAMF 13.7 (Table 4 ; analysis numbers $422-33$ ). Associated with this increase is a decrease in silica from about $28 \mathrm{wt} . \%$ at SAMF 13 to about 18 wt.\% at SAMF 13.7 , and a decrease of about 0.5 wt.\% in $\mathrm{MgO}$. Potassium contents vary between 0.1 and 2 wt. $\% \mathrm{~K}_{2} \mathrm{O}$, but average about $0.3-0.4$ wt. $\%$; calcium contents are $2-3$ wt.\% $\mathrm{CaO}$ (Table 4 ). All other elements show little variation. These phases plot well outside the field of 2:1 clay minerals (Fig. 1) and there is no reason to suppose that parameters such as SAMF or "inter-layer" charge have any structural significance.

The compositions are similar to iron oxyhydroxides analyzed by Pritchard (1979a) from DSDP Legs 51-53 and by Adamson (1984) from DSDP Hole 504B. Iron oxyhydroxides have been described in basalts from DSDP Leg 34 by Bass (1976) and Seyfried et al. (1978), from Leg 37 by Baragar et al. (1977) and Andrews (1977, 1980), from Leg 46 by Böhlke et al. (1980), from Leg 49 by Pritchard (1979a) and Pritchard et al. (1979), from Legs 51-53 by Pritchard (1979b), Pertsev and Rusinov (1979), and Alt and Honnorez (1984), and from Leg 60 by Lawrence and Natland (1981), Natland and Mahoney (1981), and Natland and Hekinian (1981). Iron oxyhydroxides in all these cases are associated with red, orange, and yellow oxidation halos and with potassium-rich saponites and protoceladonites. In Hole 648B, the iron-oxyhydroxides are associated with potassium-rich saponites and protoceladonites in dark bands.

\section{Manganese-rich analyses}

Table 5 lists five manganese-rich analyses from Hole 648B, calculated on the assumption that iron and manganese are present entirely in their most oxidized states. The close approximation of the analysis totals to $100 \%$ suggests that this is a reasonable assumption. Calculated $\mathrm{MnO}_{2}$ contents vary up to $86 \%$ by weight. Similar manganese-rich analyses have been reported by Kurnosov et al. (1983) from DSDP Hole 501, by Böhlke et al. (1980) from DSDP Leg 46, and by Adamson (1984) from DSDP Hole 504B. The high silica and iron contents of analyses 3 through 5 suggest they represent dispersed manganese oxides associated with clay minerals or iron oxyhydroxides.

\section{X-ray diffractometry results}

Samples containing Type 1 and Type 2 halos were selected for X-ray diffraction analysis and prepared using the methods described above. In the case of the Type 2 halos, the samples included both the light and dark portions of the halo. Clay minerals are present in the thin sections of all samples X-rayed.

All diffractograms are dominated by primary plagioclase peaks. Two samples out of the eight X-rayed exhibited peaks with high d-spacings demonstrating the presence of clay minerals. The 001 smectite peak was located at $13.54 \AA$ in Sample 106-648B-1-1, 32-34 cm, and at $13.26 \AA$ in Sample 106-648B-1-3, 0-5 cm; intensities were low in both cases, possibly the result of low concentration or poor crystallinity. The samples were not glycolated because the peaks were considered too weak for further study. However, these results compare favorably with those reported by the Shipboard Scientific Party (1988) who identified smectites in three different samples, including a sample scraped from a fracture 
Table 3. Potassium-rich analyses from Hole 648B.

\begin{tabular}{|c|c|c|c|c|c|c|c|c|c|c|c|c|c|c|c|}
\hline $\begin{array}{c}\text { Sample }{ }^{\mathrm{a}} \\
\text { Anal. No. }\end{array}$ & $\begin{array}{c}13 \\
393\end{array}$ & $\stackrel{3}{342}$ & $\begin{array}{c}5 \\
395\end{array}$ & $\begin{array}{c}10 \\
262\end{array}$ & $\begin{array}{l}11 \mathrm{~A} \\
290\end{array}$ & $\begin{array}{c}13 \\
372\end{array}$ & $\begin{array}{c}13 \\
385\end{array}$ & $\begin{array}{c}13 \\
389\end{array}$ & $\begin{array}{c}13 \\
390\end{array}$ & $\begin{array}{c}13 \\
391\end{array}$ & $\begin{array}{l}16 \\
32\end{array}$ & $\begin{array}{c}3 \\
335\end{array}$ & $\begin{array}{c}3 \\
338\end{array}$ & $\begin{array}{c}4 \\
413\end{array}$ & $\begin{array}{c}5 \\
398\end{array}$ \\
\hline $\mathrm{SiO}_{2}$ & 50.20 & 45.84 & 47.59 & 45.50 & 46.97 & 50.65 & 51.30 & 52.91 & 51.10 & 52.69 & 48.01 & 43.91 & 47.83 & 48.48 & 47.53 \\
\hline $\mathrm{TiO}_{2}^{-}$ & 0.09 & 0.04 & 0.09 & 0.12 & 0.06 & 0.00 & 0.04 & 0.05 & 0.02 & 0.08 & 0.00 & 0.08 & 0.04 & 0.05 & 0.02 \\
\hline $\mathrm{Al}_{2} \hat{\mathrm{O}}_{3}$ & 0.20 & 1.21 & 2.07 & 3.62 & 2.00 & 0.07 & 0.05 & 0.04 & 0.15 & 0.21 & 1.62 & 3.49 & 0.77 & 0.63 & 1.43 \\
\hline $\mathrm{Fe}_{2}^{-} \mathrm{O}_{3}$ & 28.05 & 30.04 & 28.72 & 26.71 & 28.39 & 29.30 & 28.67 & 27.63 & 28.66 & 27.56 & 29.55 & 27.32 & 29.52 & 29.75 & 29.64 \\
\hline $\mathrm{FeO}$ & 6.32 & 6.77 & 6.47 & 6.02 & 6.40 & 6.60 & 6.46 & 6.23 & 6.46 & 6.21 & 6.66 & 6.16 & 6.65 & 6.70 & 6.68 \\
\hline $\mathrm{FeO}(\mathrm{T})$ & 31.60 & 33.84 & 32.36 & 30.09 & 31.98 & 33.01 & 32.30 & 31.13 & 32.29 & 31.05 & 33.39 & 30.78 & 33.26 & 33.52 & 33.39 \\
\hline $\mathrm{MnO}$ & 0.05 & 0.11 & 0.13 & 0.10 & 0.05 & 0.09 & 0.13 & 0.05 & 0.10 & 0.09 & 0.00 & 0.20 & 0.08 & 0.04 & 0.10 \\
\hline $\mathrm{MgO}$ & 3.05 & 3.13 & 2.97 & 3.19 & 3.49 & 3.54 & 3.53 & 4.10 & 3.69 & 4.03 & 3.24 & 3.62 & 3.48 & 3.88 & 2.98 \\
\hline $\mathrm{CaO}$ & 0.93 & 0.54 & 0.49 & 0.43 & 0.38 & 0.09 & 0.26 & 0.31 & 0.55 & 0.57 & 0.30 & 0.46 & 0.21 & 0.51 & 0.51 \\
\hline $\mathrm{Na}_{2} \mathrm{O}$ & 0.61 & 0.70 & 0.25 & 0.38 & 0.41 & 0.38 & 0.23 & 0.44 & 0.26 & 0.24 & 0.57 & 0.38 & 0.18 & 0.28 & 0.36 \\
\hline $\mathrm{K}_{2} \mathrm{O}$ & 5.26 & 5.36 & 5.41 & 6.18 & 6.54 & 4.99 & 4.70 & 4.36 & 4.46 & 4.65 & 6.54 & 6.93 & 6.19 & 5.46 & 5.46 \\
\hline $\mathrm{SO}_{3}$ & 0.30 & 0.17 & 0.07 & 0.03 & 0.08 & 0.14 & 0.07 & 0.03 & 0.07 & 0.07 & 0.00 & 0.11 & 0.03 & 0.02 & 0.05 \\
\hline Total & 95.27 & 94.05 & 94.32 & 92.40 & 94.87 & 95.98 & 95.57 & 96.29 & 95.61 & 96.54 & 96.49 & 92.85 & 95.09 & 95.93 & 94.82 \\
\hline $\mathrm{Si}$ & 7.45 & 7.03 & 7.18 & 7.02 & 7.10 & 7.46 & 7.54 & 7.64 & 7.51 & 7.61 & 7.15 & 6.83 & 7.22 & 7.22 & 7.17 \\
\hline $\mathrm{Al}$ & 0.03 & 0.22 & 0.37 & 0.66 & 0.36 & 0.01 & 0.01 & 0.01 & 0.03 & 0.04 & 0.28 & 0.64 & 0.14 & 0.11 & 0.25 \\
\hline $\mathrm{Al}$ & 0.00 & 0.00 & 0.00 & 0.00 & 0.00 & 0.00 & 0.00 & 0.00 & 0.00 & 0.00 & 0.00 & 0.00 & 0.00 & 0.00 & 0.00 \\
\hline $\mathrm{Ti}$ & 0.01 & 0.00 & 0.01 & 0.01 & 0.01 & 0.00 & 0.00 & 0.01 & 0.00 & 0.01 & 0.00 & 0.01 & 0.00 & 0.01 & 0.00 \\
\hline $\mathrm{Fe} 3$ & 3.13 & 3.47 & 3.26 & 3.10 & 3.23 & 3.25 & 3.17 & 3.00 & 3.17 & 2.99 & 3.31 & 3.20 & 3.35 & 3.34 & 3.37 \\
\hline $\mathrm{Fe} 2$ & 0.78 & 0.87 & 0.82 & 0.78 & 0.81 & 0.81 & 0.79 & 0.75 & 0.79 & 0.75 & 0.77 & 0.80 & 0.84 & 0.84 & 0.84 \\
\hline $\mathrm{Mn}$ & 0.01 & 0.01 & 0.02 & 0.01 & 0.01 & 0.01 & 0.02 & 0.01 & 0.01 & 0.01 & 0.01 & 0.03 & 0.01 & 0.01 & 0.01 \\
\hline $\mathrm{Mg}$ & 0.67 & 0.72 & 0.67 & 0.73 & 0.79 & 0.78 & 0.77 & 0.88 & 0.81 & 0.87 & 0.72 & 0.84 & 0.78 & 0.86 & 0.67 \\
\hline $\mathrm{Ca}$ & 0.15 & 0.09 & 0.08 & 0.07 & 0.06 & 0.01 & 0.04 & 0.05 & 0.09 & 0.09 & 0.05 & 0.08 & 0.03 & 0.08 & 0.08 \\
\hline $\mathrm{Na}$ & 0.18 & 0.21 & 0.07 & 0.11 & 0.12 & 0.11 & 0.07 & 0.12 & 0.07 & 0.07 & 0.16 & 0.11 & 0.05 & 0.08 & 0.11 \\
\hline K & 1.00 & 1.05 & 1.04 & 1.22 & 1.26 & 0.94 & 0.88 & 0.80 & 0.84 & 0.86 & 1.24 & 1.38 & 1.19 & 1.04 & 1.05 \\
\hline SAI & 12.07 & 12.30 & 12.30 & 12.29 & 12.29 & 12.30 & 12.29 & 12.29 & 12.30 & 12.25 & 12.30 & 12.31 & 12.33 & 12.37 & 12.31 \\
\hline $\mathrm{Al}+\mathrm{Fe}^{3+}$ & 3.17 & 3.69 & 3.63 & 3.76 & 3.59 & 3.26 & 3.18 & 3.01 & 3.19 & 3.03 & 3.60 & 3.84 & 3.49 & 3.45 & 3.62 \\
\hline$(\mathrm{EX}+)$ & 1.47 & 1.43 & 1.27 & 1.47 & 1.51 & 1.07 & 1.03 & 1.02 & 1.08 & 1.10 & 1.50 & 1.64 & 1.31 & 1.28 & 1.32 \\
\hline Sample & 6 & 6 & 8 & $11 \mathrm{~B}$ & $11 \mathrm{~B}$ & $11 \mathrm{~B}$ & 3 & 4 & 4 & 5 & 8 & 10 & $11 \mathrm{~A}$ & 12 & 12 \\
\hline Anal. $\mathrm{N}$ & 249 & 257 & 432 & 4 & 5 & 7 & 193 & 409 & 417 & 330 & 434 & 282 & 284 & 27 & 51 \\
\hline $\mathrm{SiO}_{2}$ & 48.01 & 45.79 & 45.69 & 45.98 & 44.26 & 47.69 & 45.98 & 45.90 & 44.76 & 45.98 & 48.05 & 42.33 & 43.48 & 46.42 & 46.80 \\
\hline $\mathrm{Ti}$ & 0.07 & 0.00 & 0.05 & 0.00 & 0.00 & 0.04 & 0.05 & 0.03 & 0.15 & 0.12 & 0.03 & 0.04 & 0.00 & 0.00 & 0.00 \\
\hline $\mathrm{Al}_{2} \mathrm{O}_{3}$ & 1.10 & 0.97 & 1.18 & 3.40 & 3.39 & 3.47 & 0.94 & 1.33 & 1.55 & 0.70 & 1.48 & 0.71 & 0.70 & 0.00 & 0.54 \\
\hline $\mathrm{Fe}_{2} \mathrm{O}_{3}$ & 28.22 & 30.87 & 31.06 & 28.55 & 30.32 & 29.07 & 29.31 & 31.65 & 32.16 & 30.74 & 27.02 & 33.63 & 33.01 & 33.36 & 30.67 \\
\hline $\mathrm{FeO}$ & 6.36 & 6.96 & 7.00 & 6.43 & 6.83 & 6.55 & 6.60 & 7.13 & 7.25 & 6.93 & 6.09 & 7.58 & 7.44 & 7.52 & 6.91 \\
\hline $\mathrm{FeO}(\mathrm{T})$ & 31.79 & 34.78 & 34.99 & 32.16 & 34.16 & 32.75 & 33.02 & 35.66 & 36.23 & 34.63 & 30.44 & 37.89 & 37.19 & 37.58 & 34.55 \\
\hline $\mathrm{MnO}$ & 0.21 & ; & 0. & 0.00 & 0.00 & 0.00 & 0.1 & 0.09 & 0.16 & 0.10 & 0.07 & 0.10 & 0.14 & 0.00 & 0.10 \\
\hline $\mathrm{MgO}$ & & & & & & 3. & 5. & & & & & & & 3.77 & 4.68 \\
\hline $\mathrm{CaO}$ & 0.53 & 0.45 & 0. & 0. & 0.78 & 0. & 0.4 & 0. & 0.4 & 0.71 & 0.54 & 0.38 & 0.23 & 0.82 & 1.17 \\
\hline $\mathrm{Na}_{2} \mathrm{O}$ & 0.25 & 0.59 & 0.58 & 0.00 & 0.69 & 0.0 & 0.39 & 0.3 & 0.36 & 0.38 & 0.46 & 0.49 & 0.71 & 0.00 & 0.07 \\
\hline $\mathrm{K}_{2} \mathrm{O}$ & 5.47 & 4.85 & 4.39 & 6.34 & 6.05 & 6.05 & 2.69 & 4.98 & 5.32 & 3.32 & 4.55 & 4.79 & 5.39 & 4.52 & 2.27 \\
\hline $\mathrm{SO}_{3}$ & 0.03 & 0.01 & 0.04 & 0.00 & 0.00 & 0.00 & 0.15 & 0.04 & 0.03 & 0.07 & 0.02 & 0.04 & 0.18 & 0.00 & 0.02 \\
\hline Total & 94.14 & 94.34 & 94.65 & 94.52 & 95.07 & 97.13 & 92.13 & 96.23 & 96.26 & 94.08 & 94.85 & 93.27 & 95.04 & 96.40 & 93.28 \\
\hline $\mathrm{Si}$ & & & & & & & 7.0 & & & & & & & & 7.11 \\
\hline Al & 0.20 & 0. & & & 0 & 0 & 0 . & & & 0. & 0.26 & 0.13 & 0.13 & 0.00 & 0.10 \\
\hline Al & 0.00 & 0. & & & & 0. & 0. & & & & & 0. & & 0 & 0.00 \\
\hline $\mathrm{Ti}$ & 01 & 0.0 & & & & & 0 & & & & & & & 0.00 & 0.00 \\
\hline $\mathrm{Fe} 3$ & & & & & & & & & & & & & & & 3.50 \\
\hline $\mathrm{Fe} 2$ & 0.80 & 0.89 & 0. & 0. & 0. & 0. & 0. & 0 . & & 0. & 0. & 1.00 & 0.96 & 0.95 & 0.88 \\
\hline Mn & & & & & & & & & & & & 0. & 0 & 0 & 0.01 \\
\hline $\mathrm{Mg}$ & 0.84 & 0.84 & 0.87 & 0. & 0.63 & 0. & 1.2 & 0. & 0 . & 1.09 & 1.41 & 0.74 & 0. & 0.85 & 1.06 \\
\hline $\mathrm{Ca}$ & & & & & & & & & & & 0. & 0. & 0 & 0 & 0.19 \\
\hline $\mathrm{Na}$ & 0.0 & 0. & 0. & 0.00 & 0.20 & 0.00 & 0. & 0. & 0. & 0.11 & 0.13 & 0.15 & 0.21 & 0.00 & 0.02 \\
\hline K & 1.05 & 0.95 & 0.85 & 1.23 & 1.18 & 1.13 & 0.53 & 0.95 & 1.03 & 0.64 & 0.86 & 0.97 & 1.06 & 0.87 & 0.44 \\
\hline & 12.31 & 12.4 & 12.4 & 12.3 & 12.3 & 12. & 12. & 12. & 12. & 12. & 12. & 12. & 12. & 12.56 & 12.64 \\
\hline & 3.4 & 3. & 3. & 3.8 & 4.1 & 3. & 3. & 3. & 3. & 3. & 3. & 4.13 & 3.97 & 3.78 & 3.60 \\
\hline (EX & 1.30 & 1.27 & 1.25 & 1.42 & 1.64 & 1.30 & 0.79 & 1.23 & 1.29 & 0.99 & 1.17 & 1.25 & 1.35 & 1.13 & 0.84 \\
\hline
\end{tabular}

surface. The failure to obtain clear clay mineral diffractions is attributable to the low abundances of clay in the rocks. The absence of $10 \AA$ peaks may also be due to the paucity of secondary minerals, although their absence is consistent with the geochemical evidence, namely that the potassium-rich clay minerals are protoceladonites and not true celadonite.

Iron oxyhydroxides were also present in the X-rayed samples, but since these phases are probably crystallographically amorphous they should not give rise to diffraction lines.

\section{Correlation of chemical and petrographic characteristics}

Most of the Trend 1 analyses from Hole 684B (protoceladonites) correspond to the olive-green and yellow clay minerals described from the alteration halos in the petrography section of this paper. We could not detect a petrographic distinction between the dioctahedral, potassium-rich analyses and the more trioctahedral, lower potassium analyses. The 
Table 3. (continued).

\begin{tabular}{|c|c|c|c|c|c|c|c|c|c|c|c|c|c|c|c|}
\hline $\begin{array}{c}\text { Sample } \\
\text { Anal. No. }\end{array}$ & $\begin{array}{c}18 \\
134\end{array}$ & $\begin{array}{c}1 \\
92\end{array}$ & $\begin{array}{c}3 \\
345\end{array}$ & $\begin{array}{c}4 \\
353\end{array}$ & $\begin{array}{c}5 \\
326\end{array}$ & $\begin{array}{l}12 \\
19\end{array}$ & $\begin{array}{l}12 \\
52\end{array}$ & $\begin{array}{c}18 \\
125\end{array}$ & $\begin{array}{c}19 \\
363\end{array}$ & $\begin{array}{c}20 \\
146\end{array}$ & $\begin{array}{c}20 \\
152\end{array}$ & $\begin{array}{c}4 \\
111\end{array}$ & $\begin{array}{c}7 \\
116\end{array}$ & $\begin{array}{c}13 \\
378\end{array}$ & $\begin{array}{l}19 \\
46\end{array}$ \\
\hline $\mathrm{SiO}_{2}$ & 42.75 & 43.92 & 40.84 & 44.90 & 43.72 & 44.82 & 43.68 & 42.66 & 44.75 & 43.09 & 43.20 & 38.41 & 35.43 & 33.87 & 41.00 \\
\hline $\mathrm{TiO}_{2}$ & 0.01 & 0.06 & 0.01 & 0.11 & 0.05 & 0.00 & 0.07 & 0.01 & 0.02 & 0.09 & 0.00 & 0.05 & 0.07 & 0.01 & 0.00 \\
\hline $\mathrm{Al}_{2} \mathrm{O}_{3}$ & 0.04 & 1.58 & 2.16 & 2.54 & 0.29 & 0.78 & 0.66 & 0.42 & 1.16 & 0.20 & 0.12 & 0.94 & 1.32 & 2.24 & 0.39 \\
\hline $\mathrm{Fe}_{2} \mathrm{O}_{3}$ & 35.26 & 30.97 & 33.22 & 29.81 & 32.02 & 33.04 & 31.68 & 34.79 & 28.79 & 34.03 & 34.72 & 34.23 & 36.37 & 35.28 & 36.39 \\
\hline $\mathrm{FeO}$ & 7.94 & 6.98 & 7.49 & 6.72 & 7.21 & 7.44 & 7.14 & 7.84 & 6.49 & 7.67 & 7.82 & 7.71 & 8.19 & 7.95 & 8.20 \\
\hline $\mathrm{FeO}(\mathrm{T})$ & 39.72 & 34.89 & 37.43 & 33.58 & 36.07 & 37.22 & 35.69 & 39.19 & 32.43 & 38.34 & 39.11 & 38.56 & 40.97 & 39.74 & 41.00 \\
\hline $\mathrm{MnO}$ & 0.13 & 0.18 & 0.16 & 0.13 & 0.07 & 0.00 & 0.12 & 0.13 & 0.34 & 0.22 & 0.20 & 0.22 & 0.26 & 0.33 & 0.00 \\
\hline $\mathrm{MgO}$ & 2.95 & 5.95 & 4.07 & 5.52 & 4.85 & 5.60 & 4.57 & 3.51 & 7.01 & 4.02 & 4.24 & 4.88 & 3.96 & 4.21 & 4.78 \\
\hline $\mathrm{CaO}$ & 0.38 & 0.98 & 0.40 & 1.11 & 0.85 & 0.63 & 1.04 & 0.69 & 1.81 & 0.46 & 0.58 & 0.60 & 0.92 & 0.45 & 0.98 \\
\hline $\mathrm{Na}_{2} \mathrm{O}$ & 0.32 & 0.22 & 0.62 & 0.25 & 0.33 & 0.00 & 0.08 & 0.36 & 0.90 & 0.41 & 0.25 & 0.42 & 0.56 & 0.39 & 0.00 \\
\hline $\mathrm{K}_{2} \mathrm{O}$ & 3.54 & 1.50 & 4.07 & 2.70 & 2.68 & 3.22 & 2.55 & 2.59 & 1.57 & 2.52 & 2.26 & 2.09 & 1.97 & 2.23 & 2.82 \\
\hline $\mathrm{SO}_{3}$ & 0.11 & 0.07 & 0.06 & 0.10 & 0.05 & 0.00 & 0.05 & 0.06 & 0.18 & 0.04 & 0.11 & 0.05 & 0.06 & 0.20 & 0.00 \\
\hline Total & 93.50 & 92.54 & 93.29 & 94.01 & 92.31 & 95.53 & 91.67 & 93.14 & 93.39 & 92.87 & 93.53 & 89.69 & 89.27 & 87.70 & 94.56 \\
\hline $\mathrm{Si}$ & 6.72 & 6.75 & 6.44 & 6.78 & 6.83 & 6.77 & 6.85 & 6.69 & 6.80 & 6.75 & 6.72 & 6.32 & 5.98 & 5.82 & 6.42 \\
\hline $\mathrm{Al}$ & 0.01 & 0.29 & 0.40 & 0.45 & 0.05 & 0.14 & 0.12 & 0.08 & 0.21 & 0.04 & 0.02 & 0.18 & 0.26 & 0.45 & 0.07 \\
\hline $\mathrm{Al}$ & 0.00 & 0.00 & 0.00 & 0.00 & 0.00 & 0.00 & 0.00 & 0.00 & 0.00 & 0.00 & 0.00 & 0.00 & 0.00 & 0.00 & 0.00 \\
\hline $\mathrm{Ti}$ & 0.00 & 0.01 & 0.00 & 0.01 & 0.01 & 0.00 & 0.01 & 0.00 & 0.00 & 0.01 & 0.00 & 0.01 & 0.01 & 0.00 & 0.00 \\
\hline $\mathrm{Fe} 3$ & 4.17 & 3.58 & 3.94 & 3.39 & 3.77 & 3.76 & 3.74 & 4.11 & 3.29 & 4.01 & 4.06 & 4.24 & 4.62 & 4.56 & 4.29 \\
\hline $\mathrm{Fe} 2$ & 1.05 & 0.90 & 0.99 & 0.85 & 0.94 & 0.94 & 0.94 & 1.03 & 0.82 & 1.00 & 1.02 & 1.06 & 1.16 & 1.14 & 1.07 \\
\hline $\mathrm{Mn}$ & 0.02 & 0.02 & 0.02 & 0.02 & 0.01 & 0.00 & 0.02 & 0.02 & 0.04 & 0.03 & 0.03 & 0.03 & 0.04 & 0.05 & 0.00 \\
\hline $\mathrm{Mg}$ & 0.69 & 1.36 & 0.96 & 1.24 & 1.13 & 1.26 & 1.07 & 0.82 & 1.59 & 0.94 & 0.98 & 1.20 & 1.00 & 1.08 & 1.11 \\
\hline $\mathrm{Ca}$ & 0.06 & 0.16 & 0.07 & 0.18 & 0.14 & 0.10 & 0.17 & 0.12 & 0.29 & 0.08 & 0.10 & 0.11 & 0.17 & 0.08 & 0.16 \\
\hline $\mathrm{Na}$ & 0.10 & 0.07 & 0.19 & 0.07 & 0.10 & 0.00 & 0.02 & 0.11 & 0.27 & 0.12 & 0.08 & 0.13 & 0.18 & 0.13 & 0.00 \\
\hline $\mathrm{K}$ & 0.71 & 0.29 & 0.82 & 0.52 & 0.53 & 0.62 & 0.51 & 0.52 & 0.30 & 0.50 & 0.45 & 0.44 & 0.42 & 0.49 & 0.56 \\
\hline SAMF, & 12.64 & 12.88 & 12.73 & 12.72 & 12.73 & 12.87 & 12.72 & 12.73 & 12.71 & 12.74 & 12.81 & 13.00 & 13.01 & 13.06 & 12.96 \\
\hline $\mathrm{Al}+\mathrm{Fe}^{3+}$ & 4.18 & 3.87 & 4.35 & 3.84 & 3.82 & 3.90 & 3.86 & 4.18 & 3.50 & 4.05 & 4.09 & 4.42 & 4.88 & 5.02 & 4.36 \\
\hline$(\mathrm{EX}+)$ & 0.94 & 0.68 & 1.14 & 0.95 & 0.92 & 0.82 & 0.88 & 0.86 & 1.16 & 0.78 & 0.72 & 0.78 & 0.94 & 0.78 & 0.89 \\
\hline Sample ${ }^{\mathrm{a}}$ & 19 & 20 & 20 & 20 & 20 & & & & & & & & & & \\
\hline Anal. No. & 366 & 145 & 150 & 151 & 159 & & & & & & & & & & \\
\hline $\mathrm{SiO}_{2}$ & 46.75 & 40.93 & 41.06 & 41.94 & 43.80 & & & & & & & & & & \\
\hline $\mathrm{TiO}_{2}$ & 0.00 & 0.00 & 0.06 & 0.00 & 0.04 & & & & & & & & & & \\
\hline $\mathrm{Al}_{2} \mathrm{O}_{3}$ & 0.89 & 0.30 & 0.43 & 0.24 & 0.88 & & & & & & & & & & \\
\hline $\mathrm{Fe}_{2} \mathrm{O}_{3}$ & 26.39 & 35.76 & 34.72 & 34.75 & 27.90 & & & & & & & & & & \\
\hline $\mathrm{FeO}$ & 5.95 & 8.06 & 7.82 & 7.83 & 6.29 & & & & & & & & & & \\
\hline $\mathrm{FeO}(\mathrm{T})$ & 29.73 & 40.29 & 39.11 & 39.15 & 31.43 & & & & & & & & & & \\
\hline $\mathrm{MnO}$ & 0.16 & 0.27 & 0.23 & 0.27 & 0.13 & & & & & & & & & & \\
\hline $\mathrm{MgO}$ & 10.29 & 4.57 & 6.51 & 5.95 & 7.55 & & & & & & & & & & \\
\hline $\mathrm{CaO}$ & 0.80 & 0.65 & 0.56 & 0.50 & 0.58 & & & & & & & & & & \\
\hline $\mathrm{Na}_{2} \mathrm{O}$ & 0.73 & 0.33 & 0.48 & 0.29 & 0.17 & & & & & & & & & & \\
\hline $\mathrm{K}_{2} \mathrm{O}$ & 2.20 & 1.81 & 1.64 & 1.52 & 1.70 & & & & & & & & & & \\
\hline $\mathrm{SO}_{3}$ & 0.01 & 0.19 & 0.13 & 0.08 & 0.14 & & & & & & & & & & \\
\hline Total & 94.27 & 92.99 & 93.72 & 93.46 & 89.37 & & & & & & & & & & \\
\hline $\mathrm{Si}$ & 6.93 & 6.46 & 6.40 & 6.53 & 6.89 & & & & & & & & & & \\
\hline $\mathrm{Al}$ & 0.16 & 0.06 & 0.08 & 0.04 & 0.16 & & & & & & & & & & \\
\hline $\mathrm{Al}$ & 0.00 & 0.00 & 0.00 & 0.00 & 0.00 & & & & & & & & & & \\
\hline $\mathrm{Ti}$ & 0.00 & 0.00 & 0.01 & 0.00 & 0.00 & & & & & & & & & & \\
\hline $\mathrm{Fe} 3$ & 2.94 & 4.25 & 4.07 & 4.07 & 3.30 & & & & & & & & & & \\
\hline $\mathrm{Fe} 2$ & 0.74 & 1.06 & 1.02 & 1.02 & 0.83 & & & & & & & & & & \\
\hline $\mathrm{Mn}$ & 0.02 & 0.04 & 0.03 & 0.04 & 0.02 & & & & & & & & & & \\
\hline $\mathrm{Mg}$ & 2.27 & 1.08 & 1.51 & 1.38 & 1.77 & & & & & & & & & & \\
\hline $\mathrm{Ca}$ & 0.13 & 0.11 & 0.09 & 0.08 & 0.10 & & & & & & & & & & \\
\hline $\mathrm{Na}$ & 0.21 & 0.10 & 0.15 & 0.09 & 0.05 & & & & & & & & & & \\
\hline K & 0.42 & 0.36 & 0.33 & 0.30 & 0.34 & & & & & & & & & & \\
\hline SAMF & 13.04 & 12.91 & 13.09 & 13.05 & 12.96 & & & & & & & & & & \\
\hline $\mathrm{Al}+\mathrm{Fe}^{3+}$ & 3.10 & 4.31 & 4.15 & 4.12 & 3.47 & & & & & & & & & & \\
\hline$(\mathrm{EX}+)$ & 0.88 & 0.69 & 0.66 & 0.56 & 0.59 & & & & & & & & & & \\
\hline
\end{tabular}

Notes: a. See Table 1 for sample identification. Analysis number 393, SAMF < 12.1; 342-32, SAMF 12.1-12.3; 335-7, SAMF 12.3-12.5; 193-134, SAMF 12.5-12.7; 92-152, SAMF 12.7-12.9; 111-159, SAMF 12.9-13.1. Analyses are listed in depth order within each SAMF division. 


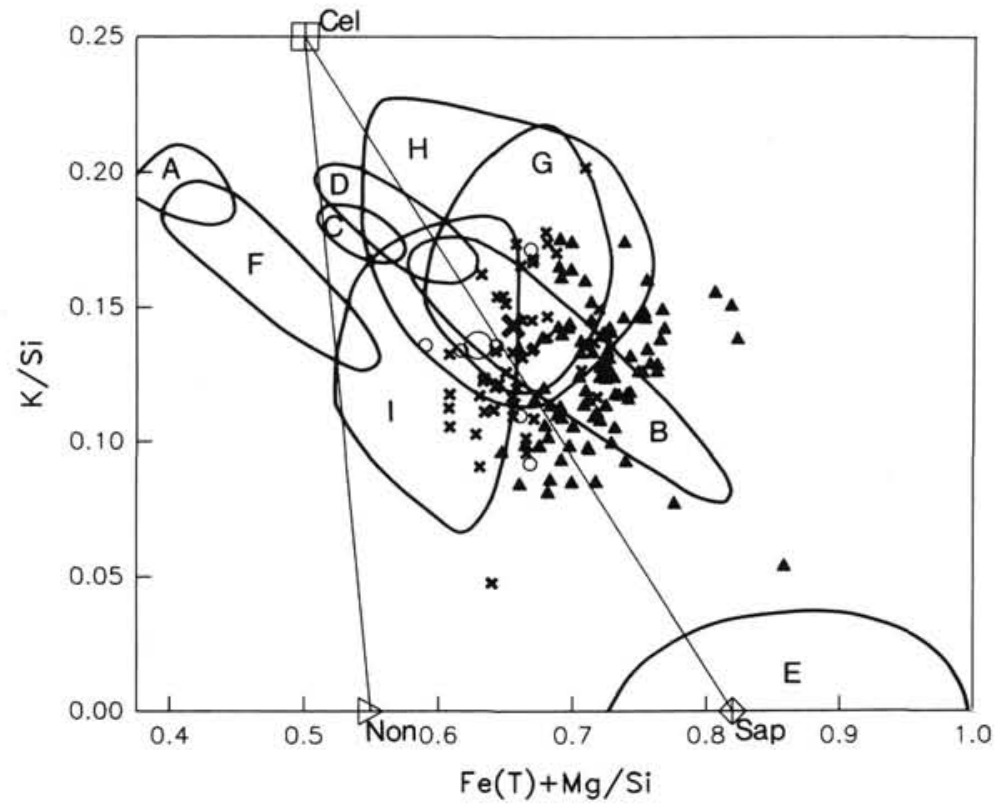

Figure 4. Diagram showing the atomic ratios $\mathrm{K} / \mathrm{Si}$ and $(\mathrm{Fe}(\mathrm{T})+\mathrm{Mg}) / \mathrm{Si}$ for potassium-rich analyses from Hole 648B, calculated assuming an iron oxidation ratio of 0.3 for comparison with celadonite and potassium-rich analyses from other oceanic basalts. A. DSDP Legs 17 and 25 (Buckley et al., 1978, Table 4), B. DSDP Leg 37 (Andrews, 1977, Table 3, and 1980, Table 4), C. DSDP Site 417 (Alt and Honnorez, 1984, Table 1, analyses 1 and 2), D. DSDP Legs 51-53 (Donelly et al., 1979, Table 1), F. DSDP Sites 458 and 459 (Natland and Mahoney, 1981, Table 2, analyses 11-14), G, H, I. DSDP Hole 504B (Honnorez et al., 1983a, Table 3b, analyses 40-46; Pertsev and Boronikhin, 1983, Tables 4, 6, 7; Adamson, 1984, Table C3.4). E. Shows the field for saponites (Donnelly et al., 1979). Sap, Non, and Cel are the positions of ideal saponite, nontronite, and celadonite. Symbols as in Figure 2.

paucity of secondary minerals in these rocks, combined with the smallness of many of the alteration features, made it difficult to collect analyses as a transect across alteration halos. The protoceladonite analyses from a given halo are very similar in composition and generally belong to the same SAMF division in Figure 1; individual analyses varying only slightly in terms of inter-layer charge and total $\left(\mathrm{Al}+\mathrm{Fe}^{3+}\right)$. Variation along Trend 1 is mainly due to variation between samples. There is a distinct tendency for relatively coarse, open space-filling protoceladonites to have very low alumina contents. This raises the question as to whether some analyses from smaller patches of clay may be alumina-contaminated from neighboring silicate grains. However, Table 1 shows that celadonite and protoceladonite analyses usually contain significant alumina.

The iron oxyhydroxide and manganese-rich analyses correspond to the isotropic red and opaque minerals identified in thin section, respectively. The chemical variation along Trends 3 and 2 toward lower SAMF corresponds approximately to the petrographic gradation between red iron oxyhydroxides and orange-red clays.

Since much of the recovery in this hole is rubble and unassignable to any lithologic depth, no conclusions can be drawn as to possible vertical variations in alteration phenomena.

\section{DISCUSSION}

In the basalts from Hole $648 \mathrm{~B}$, the only primary phases that can be seen to have been altered are sulfides, which may be completely replaced by iron oxyhydroxide, and intersertal glass, which shows only partial replacement. The latter appears to be confined to the less fine-grained, occasionally subophitic massive basalt in the lower part of the hole. The presence of submicroscopic bodies of intergranular glass in the finer grained (mainly pillowed) basalts higher in the section cannot be ruled out. If present, this glass could also be altered. However, most of the secondary phases occur as linings or fillings of fractures, micromiarolitic cavities, or vesicles. This in itself implies transport of the chemical constituents of the secondary phases (chiefly silica, iron, magnesium, potassium, manganese, and aluminum) on a scale of tens of micrometers. The migration of the dark bands of secondary minerals into the rock was probably accompanied by redissolution of earlier-formed phases at the trailing edges of the bands, and this implies chemical transport on at least a millimetric scale.

The availability of chemical constituents from unmodified seawater is very variable. If an average halo has a dark band about $3 \mathrm{~mm}$ thick, with a protoceladonite content of about $1 \%-2 \%$, then, assuming a density of $2.5 \mathrm{~g} / \mathrm{cm}^{3}$ for the protoceladonite, every square centimeter of halo will contain on the order of $10 \mathrm{mg}$ of protoceladonite, which would require the magnesium content of $0.2 \mathrm{~mL}$ of seawater, the potassium content of $1 \mathrm{~mL}$ of seawater, and the silica content of $500 \mathrm{~mL}$ of seawater. The iron content of seawater is virtually zero. Clearly, the magnesium and potassium could have been supplied by slight depletion of realistically small volumes of seawater or modified seawater. The silica and iron could either have been derived very locally from the breakdown of basalt glass, or from externally derived fluids enriched in these elements. Although such hydrothermal fluids would be depleted in magnesium, their content should be sufficient to form protoceladonite; only exhaling black smoker fluids are strongly depleted in magnesium and the basalts from Hole 648B were not affected by high temperature fluids. 
Table 4. Iron-rich analyses from Hole 648B.

\begin{tabular}{|c|c|c|c|c|c|c|c|c|c|c|c|c|c|c|c|c|}
\hline $\begin{array}{c}\text { Sample }^{\mathrm{a}} \\
\text { Anal. No. }\end{array}$ & $\begin{array}{c}3 \\
344\end{array}$ & $\begin{array}{c}8 \\
435\end{array}$ & $\begin{array}{l}16 \\
66\end{array}$ & $\begin{array}{l}16 \\
75\end{array}$ & $\begin{array}{l}16 \\
79\end{array}$ & $\begin{array}{c}19 \\
370\end{array}$ & $\begin{array}{c}2 \\
442\end{array}$ & $\begin{array}{l}12 \\
22\end{array}$ & $\begin{array}{l}16 \\
67\end{array}$ & $\begin{array}{l}19 \\
36\end{array}$ & $\begin{array}{l}19 \\
39\end{array}$ & $\begin{array}{c}19 \\
369\end{array}$ & $\begin{array}{c}4 \\
422\end{array}$ & $\begin{array}{c}7 \\
110\end{array}$ & $\begin{array}{l}12 \\
25\end{array}$ & $\begin{array}{l}12 \\
26\end{array}$ \\
\hline $\mathrm{SiO}_{2}$ & 39.94 & 36.09 & 38.40 & 36.57 & 41.39 & 40.12 & 35.29 & 35.84 & 37.81 & 38.99 & 41.01 & 32.20 & 28.39 & 26.83 & 26.37 & 26.47 \\
\hline $\mathrm{TiO}_{2}^{2}$ & 0.02 & 0.07 & 0.08 & 0.03 & 0.09 & 0.05 & 0.14 & 0.00 & 0.00 & 0.00 & 0.00 & 0.05 & 0.02 & 0.07 & 0.00 & 0.00 \\
\hline $\mathrm{Al}_{2} \mathrm{O}_{3}$ & 1.37 & 0.77 & 0.65 & 1.39 & 2.14 & 1.98 & 1.43 & 0.00 & 0.69 & 0.52 & 0.00 & 0.83 & 0.13 & 2.14 & 0.00 & 0.00 \\
\hline $\mathrm{Fe}_{2} \mathrm{O}_{3}$ & 33.03 & 34.83 & 36.46 & 32.76 & 32.76 & 34.77 & 35.52 & 39.79 & 37.16 & 37.31 & 37.78 & 40.56 & 44.22 & 41.44 & 43.01 & 44.68 \\
\hline $\mathrm{FeO}$ & 7.44 & 7.85 & 8.21 & 7.38 & 7.38 & 7.83 & 8.00 & 8.97 & 8.37 & 8.41 & 8.51 & 9.14 & 9.96 & 9.34 & 9.69 & 10.07 \\
\hline $\mathrm{FeO}(\mathrm{T})$ & 37.21 & 39.24 & 41.07 & 36.91 & 36.91 & 39.17 & 40.02 & 44.83 & 41.86 & 42.03 & 42.56 & 45.69 & 49.82 & 46.68 & 48.45 & 50.33 \\
\hline $\mathrm{MnO}$ & 0.29 & 0.11 & 0.09 & 0.19 & 0.18 & 0.18 & 0.41 & 0.78 & 0.07 & 0.00 & 0.00 & 0.21 & 0.09 & 0.32 & 0.39 & 0.00 \\
\hline $\mathrm{MgO}$ & 3.32 & 3.18 & 2.13 & 2.38 & 2.54 & 2.96 & 2.98 & 2.65 & 2.26 & 3.35 & 3.98 & 2.30 & 2.09 & 1.70 & 1.86 & 1.88 \\
\hline $\mathrm{CaO}$ & 0.88 & 1.83 & 0.70 & 0.54 & 0.35 & 0.55 & 1.77 & 1.77 & 0.69 & 0.85 & 1.19 & 1.76 & 2.96 & 2.95 & 3.41 & 3.81 \\
\hline $\mathrm{Na}_{2} \mathrm{O}$ & 0.62 & 0.66 & 0.71 & 0.34 & 0.62 & 1.36 & 0.52 & 0.00 & 0.49 & 0.65 & 0.67 & 1.24 & 0.57 & 0.83 & 0.91 & 0.76 \\
\hline $\mathrm{K}_{2} \mathrm{O}$ & 4.99 & 2.52 & 3.10 & 3.12 & 4.64 & 3.64 & 2.68 & 1.96 & 2.93 & 3.44 & 2.66 & 1.57 & 0.48 & 0.54 & 1.45 & 0.85 \\
\hline $\mathrm{SO}_{3}$ & 0.13 & 0.15 & 0.14 & 0.32 & 0.11 & 0.35 & 0.14 & 0.00 & 0.13 & 0.00 & 0.00 & 0.19 & 0.21 & 0.14 & 0.00 & 0.00 \\
\hline Total & 92.30 & 88.40 & 90.81 & 85.35 & 92.28 & 94.05 & 88.96 & 91.76 & 90.81 & 93.51 & 95.80 & 90.36 & 89.24 & 86.48 & 87.09 & 88.51 \\
\hline $\mathrm{Si}$ & 6.45 & 6.14 & 6.34 & 6.36 & 6.60 & 6.33 & 6.00 & 5.98 & 6.27 & 6.27 & 6.38 & 5.54 & 5.07 & 4.93 & 4.92 & 4.85 \\
\hline Al & 0.26 & 0.15 & 0.13 & 0.29 & 0.40 & 0.37 & 0.29 & 0.00 & 0.13 & 0.10 & 0.00 & 0.17 & 0.03 & 0.46 & 0.00 & 0.00 \\
\hline Al & 0.00 & 0.00 & 0.00 & 0.00 & 0.00 & 0.00 & 0.00 & 0.00 & 0.00 & 0.00 & 0.00 & 0.00 & 0.00 & 0.00 & 0.00 & 0.00 \\
\hline $\mathrm{Ti}$ & 0.00 & 0.01 & 0.01 & 0.00 & 0.01 & 0.01 & 0.02 & 0.00 & 0.00 & 0.00 & 0.00 & 0.01 & 0.00 & 0.01 & 0.00 & 0.00 \\
\hline $\mathrm{Fe} 3$ & 4.01 & 4.46 & 4.53 & 4.29 & 3.93 & 4.13 & 4.54 & 5.00 & 4.63 & 4.52 & 4.43 & 5.25 & 5.95 & 5.73 & 6.04 & 6.17 \\
\hline $\mathrm{Fe} 2$ & 1.00 & 1.12 & 1.13 & 1.07 & 0.98 & 1.03 & 1.14 & 1.25 & 1.16 & 1.13 & 1.11 & 1.32 & 1.49 & 1.43 & 1.51 & 1.54 \\
\hline Mn & 0.04 & 0.02 & 0.01 & 0.03 & 0.02 & 0.02 & 0.06 & 0.11 & 0.01 & 0.00 & 0.00 & 0.03 & 0.01 & 0.05 & 0.06 & 0.00 \\
\hline $\mathrm{Mg}$ & 0.80 & 0.81 & 0.52 & 0.62 & 0.60 & 0.70 & 0.75 & 0.66 & 0.56 & 0.80 & 0.92 & 0.59 & 0.56 & 0.47 & 0.52 & 0.51 \\
\hline $\mathrm{Ca}$ & 0.15 & 0.33 & 0.12 & 0.10 & 0.06 & 0.09 & 0.32 & 0.32 & 0.12 & 0.15 & 0.20 & 0.32 & 0.57 & 0.58 & 0.68 & 0.75 \\
\hline $\mathrm{Na}$ & 0.19 & 0.22 & 0.23 & 0.11 & 0.19 & 0.42 & 0.17 & 0.00 & 0.16 & 0.20 & 0.20 & 0.41 & 0.20 & 0.30 & 0.33 & 0.27 \\
\hline K & 1.03 & 0.55 & 0.65 & 0.69 & 0.94 & 0.73 & 0.58 & 0.42 & 0.62 & 0.71 & 0.53 & 0.34 & 0.11 & 0.13 & 0.35 & 0.20 \\
\hline SAMF $_{3+}$ & 12.52 & 12.68 & 12.66 & 12.63 & 12.51 & 12.55 & 12.72 & 12.89 & 12.75 & 12.82 & 12.84 & 12.87 & 13.10 & 13.02 & 12.98 & 13.08 \\
\hline $\mathrm{Al}+\mathrm{Fe}^{3+}$ & 4.27 & 4.61 & 4.66 & 4.58 & 4.33 & 4.50 & 4.83 & 5.00 & 4.77 & 4.61 & 4.43 & 5.42 & 5.98 & 6.19 & 6.04 & 6.17 \\
\hline$(\mathrm{EX}+)$ & 1.53 & 1.43 & 1.13 & 1.01 & 1.25 & 1.33 & 1.40 & 1.05 & 1.02 & 1.20 & 1.13 & 1.41 & 1.44 & 1.58 & 2.04 & 1.97 \\
\hline Sample $^{\mathrm{a}}$ & 16 & 1 & 8 & 10 & 16 & 16 & 20 & 20 & 10 & 10 & 10 & $11 \mathrm{~B}$ & 15 & 16 & $11 \mathrm{~A}$ & 16 \\
\hline Anal. No. & 77 & 95 & 428 & 278 & 65 & 83 & 155 & 156 & 272 & 273 & 276 & 2 & 59 & 82 & 285 & 33 \\
\hline $\mathrm{SiO}_{2}$ & 29.97 & 22.86 & 24.95 & 24.02 & 26.30 & 25.25 & 26.83 & 30.63 & 22.71 & 24.11 & 21.52 & 21.51 & 24.60 & 24.80 & 19.69 & 17.68 \\
\hline $\mathrm{TiO}_{2}^{2}$ & 0.09 & 0.00 & 0.02 & 0.02 & 0.00 & 0.01 & 0.05 & 0.02 & 0.00 & 0.00 & 0.04 & 0.00 & 0.07 & 0.00 & 0.40 & 0.00 \\
\hline $\mathrm{Al}_{2} \mathrm{O}_{3}$ & 0.87 & 0.13 & 1.93 & 0.04 & 0.24 & 0.18 & 0.09 & 0.22 & 0.11 & 0.14 & 0.11 & 1.42 & 0.25 & 0.64 & 0.63 & 3.74 \\
\hline $\mathrm{Fe}_{2} \mathrm{O}_{3}$ & 41.36 & 44.32 & 44.38 & 46.81 & 46.18 & 46.36 & 46.19 & 43.02 & 48.34 & 48.94 & 48.55 & 49.58 & 46.81 & 47.23 & 54.79 & 48.41 \\
\hline $\mathrm{FeO}$ & 9.32 & 9.99 & 10.00 & 10.55 & 10.41 & 10.45 & 10.41 & 9.69 & 10.89 & 11.03 & 10.94 & 11.17 & 10.55 & 10.64 & 12.35 & 10.91 \\
\hline $\mathrm{FeO}(\mathrm{T})$ & 46.60 & 49.93 & 50.00 & 52.74 & 52.03 & 52.23 & 52.04 & 48.47 & 54.46 & 55.14 & 54.70 & 55.86 & 52.74 & 53.21 & 61.73 & 54.54 \\
\hline $\mathrm{MnO}$ & 0.18 & 0.17 & 0.18 & 0.07 & 0.19 & 0.08 & 1.29 & 0.36 & 0.14 & 0.14 & 0.07 & 0.00 & 0.33 & 0.41 & 0.19 & 0.00 \\
\hline $\mathrm{MgO}$ & 1.75 & 2.01 & 1.95 & 1.37 & 1.17 & 1.30 & 2.34 & 3.57 & 1.66 & 1.71 & 1.77 & 1.67 & 2.00 & 1.48 & 1.66 & 1.72 \\
\hline $\mathrm{CaO}$ & 2.02 & 3.98 & 2.96 & 3.11 & 2.12 & 2.38 & 1.68 & 2.05 & 3.33 & 3.20 & 3.30 & 3.30 & 1.41 & 2.46 & 0.81 & 2.43 \\
\hline $\mathrm{Na}_{2} \mathrm{O}$ & 0.43 & 0.41 & 0.63 & 0.11 & 0.31 & 0.66 & 0.40 & 0.32 & 0.07 & 0.05 & 0.41 & 1.44 & 0.55 & 0.22 & 0.76 & 1.05 \\
\hline $\mathrm{K}_{2} \mathrm{O}$ & 1.55 & 0.24 & 0.27 & 0.34 & 0.35 & 0.31 & 0.41 & 0.57 & 0.25 & 0.25 & 0.38 & 1.20 & 0.33 & 0.21 & 1.87 & 1.24 \\
\hline $\mathrm{SO}_{3}$ & 0.11 & 0.18 & 0.34 & 0.15 & 0.04 & 0.26 & 0.20 & 0.28 & 0.25 & 0.16 & 0.26 & 0.00 & 0.48 & 0.28 & 0.34 & 0.00 \\
\hline Total & 87.80 & 84.41 & 88.02 & 87.12 & 87.52 & 87.33 & 90.01 & 90.82 & 88.01 & 89.98 & 87.60 & 91.30 & 87.60 & 88.50 & 93.77 & 87.18 \\
\hline $\mathrm{Si}$ & 5.37 & 4.46 & 4.58 & 4.54 & 4.87 & 4.71 & 4.82 & 5.28 & 4.29 & 4.43 & 4.12 & 3.98 & 4.58 & 4.57 & 3.61 & 3.45 \\
\hline $\mathrm{Al}$ & 0.18 & 0.03 & 0.42 & 0.01 & 0.05 & 0.04 & 0.02 & 0.04 & 0.02 & 0.03 & 0.02 & 0.31 & 0.05 & 0.14 & 0.14 & 0.86 \\
\hline Al & 0.00 & 0.00 & 0.00 & 0.00 & 0.00 & 0.00 & 0.00 & 0.00 & 0.00 & 0.00 & 0.00 & 0.00 & 0.00 & 0.00 & 0.00 & 0.00 \\
\hline $\mathrm{Ti}$ & 0.01 & 0.00 & 0.00 & 0.00 & 0.00 & 0.00 & 0.01 & 0.00 & 0.00 & 0.00 & 0.01 & 0.00 & 0.01 & 0.00 & 0.07 & 0.00 \\
\hline $\mathrm{Fe} 3$ & 5.58 & 6.50 & 6.13 & 6.66 & 6.43 & 6.51 & 6.25 & 5.58 & 6.87 & 6.76 & 6.99 & 6.90 & 6.55 & 6.56 & 7.57 & 7.11 \\
\hline $\mathrm{Fe} 2$ & 1.40 & 1.63 & 1.53 & 1.67 & 1.61 & 1.63 & 1.56 & 1.40 & 1.72 & 1.69 & 1.75 & 1.73 & 1.64 & 1.64 & 1.89 & 1.78 \\
\hline $\mathrm{Mn}$ & 0.03 & 0.03 & 0.03 & 0.01 & 0.03 & 0.01 & 0.20 & 0.05 & 0.02 & 0.02 & 0.01 & 0.00 & 0.05 & 0.06 & 0.03 & 0.00 \\
\hline $\mathrm{Mg}$ & 0.47 & 0.58 & 0.53 & 0.39 & 0.32 & 0.36 & 0.63 & 0.92 & 0.47 & 0.47 & 0.50 & 0.46 & 0.55 & 0.41 & 0.45 & 0.50 \\
\hline $\mathrm{Ca}$ & 0.39 & 0.83 & 0.58 & 0.63 & 0.42 & 0.48 & 0.32 & 0.38 & 0.67 & 0.63 & 0.68 & 0.65 & 0.28 & 0.49 & 0.16 & 0.51 \\
\hline $\mathrm{Na}$ & 0.15 & 0.15 & 0.22 & 0.04 & 0.11 & 0.24 & 0.14 & 0.11 & 0.03 & 0.02 & 0.15 & 0.52 & 0.20 & 0.08 & 0.27 & 0.40 \\
\hline K & 0.35 & 0.06 & 0.06 & 0.08 & 0.08 & 0.07 & 0.09 & 0.13 & 0.06 & 0.06 & 0.09 & 0.28 & 0.08 & 0.05 & 0.44 & 0.31 \\
\hline SAMF & 12.99 & 13.20 & 13.19 & 13.26 & 13.29 & 13.24 & 13.28 & 13.23 & 13.37 & 13.38 & 13.39 & 13.37 & 13.38 & 13.32 & 13.67 & 13.70 \\
\hline $\mathrm{Al}+\mathrm{Fe}^{3+}$ & 5.76 & 6.53 & 6.54 & 6.67 & 6.49 & 6.55 & 6.27 & 5.63 & 6.89 & 6.79 & 7.02 & 7.21 & 6.61 & 6.69 & 7.70 & 7.97 \\
\hline$(\mathrm{EX}+)$ & 1.28 & 1.88 & 1.45 & 1.38 & 1.04 & 1.26 & 0.88 & 0.99 & 1.43 & 1.34 & 1.60 & 2.11 & 0.84 & 1.10 & 1.03 & 1.72 \\
\hline
\end{tabular}

Notes: a. See Table 1 for sample identification. Analysis numbers 344-370, SAMF 12.5-12.7; 442-369, SAMF 12.7-12.9; 422-77, SAMF 12.9-13.1; 95-156, SAMF 13.1-13.3; 272-82, SAMF 13.3-13.5; 285-33, SAMF 13.5-13.7. Analyses are listed in depth order within each SAMF division. 
Assuming that analytical contamination from neighboring minerals does not account for all the aluminum in the clay analyses, the only possible source of this element in those protoceladonites that contain it is local breakdown of glass, since the concentration of aluminum in seawater and in any conceivable hydrothermal fluid is extremely low due to its being essentially immobile during alteration.

Crovisier et al. $(1985,1987)$ found that experimental rates of dissolution of basaltic glass in seawater corresponded to surface recession rates of the order of $100 \mu \mathrm{m}$ per thousand years at $3^{\circ} \mathrm{C}$, while Hekinian and Hoffert (1975) estimated rates of 2-4 $\mu \mathrm{m}$ per thousand years for natural seafloor weathering of glass on the Mid-Atlantic Ridge. These observations were made on material which is not equivalent to the interstitial glass of the Hole 648B basalts. However, if the rates of reaction of glass are broadly independent of textural location then, given that the maximum age of the Hole 648B basalts is about $50-100 \mathrm{k} . \mathrm{y}$., the possibility exists that glass could have been altered over distances greater than the size of the interstitial glass bodies, assuming that water could freely permeate the rock. This would release adequate silica and iron (and alumina) to form the observed phases.

The other possibility, that the silica and iron were externally derived, is also not unreasonable. Low temperature, silica- and iron-enriched fluids are responsible for the formation of deposits of manganese oxides and iron oxyhydroxides and silicates (chiefly nontronite) at and near mid-ocean ridge axes (Honnorez et al., 1983b; Rona, 1984, and references therein). The chemical constituents of these deposits are the same as for the secondary phases in the Hole 648B basalts, and there are close mineralogical parallels, as noted by Honnorez et al. (1983b). If this is the case, then the distribution of the low temperature hydrothermal activity that produces these deposits is likely to govern the extent to which the alteration phenomena seen in Hole 648B are developed in young oceanic crust.

Phillipsite, calcite, and saponite are minerals typical of low temperature alteration of ocean floor basalts, but they have not been found in Hole $648 \mathrm{~B}$ basalts. Although this could in principle be because they were not recovered although present, it is more probable that they have not yet formed in these very young basalts. The similarity between the protoceladonite trend reported here and that from DSDP Hole 504B (Adamson, 1984), where the basalts are $6.2 \mathrm{~m}$.y. old, may be indicative that as the basalts age further and the present oxidizing conditions become reducing with burial, saponites may develop.

A feature of the oxidative alteration seen in Hole $648 \mathrm{~B}$ is the destruction of primary sulfides once the dark band of an alteration halo has moved through the rock. It seems probable, then, that with further alteration, the primary sulfur isotopic systematics of the basalts may be obliterated within a period less than $1 \mathrm{~m}$.y., and that the primary sulfur content of ocean floor basalts is perhaps one of the most sensitive chemical indices of alteration in otherwise fresh-looking basalts.

\section{SUMMARY AND CONCLUSIONS}

The basalts recovered from Hole 648B, while predominantly fresh, do contain trace amounts of secondary phases, found on fracture surfaces and in the rock matrix near the fracture surfaces. The furthest extent of the secondary phases into the rock matrix is marked by the leading front of a dark band. The band is usually $1-4 \mathrm{~mm}$ thick and may occur directly adjacent to a fracture coated with secondary phases, or up to some centimeters into the body of the rock. The dark bands are the principal locations of secondary phases in the
Table 5. Manganese-rich analyses from Hole 648B.

\begin{tabular}{lrrrrr}
\hline & 1 & \multicolumn{1}{c}{2} & \multicolumn{1}{c}{3} & \multicolumn{1}{c}{4} & \multicolumn{1}{c}{5} \\
\hline $\mathrm{SiO}_{2}$ & 0.74 & 0.49 & 28.17 & 41.77 & 48.72 \\
$\mathrm{TiO}_{2}$ & 0.03 & 0.00 & 0.04 & 0.08 & 0.00 \\
$\mathrm{Al}_{2} \mathrm{O}_{3}$ & 0.08 & 0.13 & 0.12 & 0.13 & 0.00 \\
$\mathrm{Fe}_{2} \mathrm{O}_{3}(\mathrm{~T})$ & 4.39 & 3.23 & 23.36 & 35.84 & 31.67 \\
$\mathrm{MnO}_{2}(\mathrm{~T})$ & 85.07 & 86.20 & 35.38 & 8.89 & 5.79 \\
$\mathrm{NiO}$ & 0.27 & 0.36 & 0.18 & 0.09 & - \\
$\mathrm{MgO}$ & 4.72 & 5.28 & 5.05 & 4.07 & 5.83 \\
$\mathrm{CaO}$ & 1.89 & 1.80 & 1.15 & 0.79 & 0.91 \\
$\mathrm{Na}_{2} \mathrm{O}$ & 3.26 & 3.10 & 0.68 & 0.70 & 0.00 \\
$\mathrm{~K}_{2} \mathrm{O}$ & 1.25 & 1.23 & 2.86 & 3.93 & 3.49 \\
$\mathrm{SO}_{3}$ & 0.23 & 0.24 & 0.07 & 0.06 & - \\
$\mathrm{Cl}$ & 0.11 & 0.13 & 0.06 & 0.04 & - \\
& & & & & \\
$\mathrm{T}$ tal & 102.04 & 102.19 & 97.12 & 96.36 & 96.41 \\
& & & & &
\end{tabular}

Analyses calculated assuming complete oxidation of both $\mathrm{Fe}$ and $\mathrm{Mn}$. - denotes no data. Analyses 1 and 2 from opaque layers lining large vug in sample 10 . Analyses 3 and 4 from dark patches within green-yellow clay filling of miarolitic cavity in Sample 4. Analysis 5 from nearly opaque iron oxyhydroxide lining of microvesicle in Sample 12. See Table 1 for details of samples.

rock matrix. These phases include olive-green to yellow clays, with compositions and inferred structure corresponding to protoceladonite, and red to opaque iron oxyhydroxides and rare manganese oxides. These phases show a crude zonation, both with respect to the leading fronts of halos and within vesicle linings. The general (but not rigid) paragenetic sequence appears to be olive-green protoceladonite then yellow protoceladonite, then red to opaque iron (and manganese) oxyhydroxides.

The alteration phenomena in Hole 648B may have arisen by the action of ambient seawater and/or advecting lowtemperature fluids of hydrothermal origin. The action of the latter is implied if the intersertal and intergranular glass is inadequate (e.g., in the finer grained basalts) to supply the silica and more especially the iron in the secondary phases through the alteration of primary sulfides. Some of the protoceladonite analyses contain significant alumina, which would suggest that such phases formed at least in part from in situ alteration of intergranular or intersertal glass, although they may possibly be contaminated by alumina from adjacent plagioclase and pyroxene during probing. Other aluminosilicates (including olivine) are optically fresh. Sulfides are the only primary minerals to be completely altered in places. A feature of the alteration halos is that they migrate through the rock without leaving extensive deposits of secondary phases.

\section{ACKNOWLEDGMENTS}

Adamson acknowledges the support of the U.S. Science Advisory Council with respect to funding for electron microprobe time, and thanks Dwight Deuring, Amy Russell, Mary Ann Cusimano, and Audrey Meyer for their advice and help at various stages of this study. Richards acknowledges the funding of his participation in Leg 109 by the U.K. Natural Environment Research Council and thanks Tim Hopkins and Dave Plant for assistance with microprobe analysis. The study benefitted from discussions with Jose Honnorez and Kathy Gillis.

\section{REFERENCES}

Adamson, A. C., 1983. Chemistry of alteration minerals from Deep Sea Drilling Project Sites 501, 504, and 505. In Cann, J. R., Langseth, M. G., Honnorez, J., Von Herzen, R. P., White, S. M., et al., Init. Repts. DSDP, 69: Washington (U.S. Govt. Printing Office), 551-564. 
1984. Hydrothermal petrology in the Costa Rica Rift [Ph.D. thesis]. University of Newcastle upon Tyne, U.K.

Alt, J. C., and Honnorez, J., 1984. Alteration of the upper oceanic crust: DSDP Site 417: Mineralogy and chemistry. Contrib. Mineral. Petrol., 87:149-169.

Andrews, A. J., 1977. Low temperature fluid alteration of oceanic layer 2 basalts, DSDP Leg 37. Can. J. Earth Sci., 14:911-926.

1980. Saponite and celadonite in layer 2 basalts, DSDP Leg 37. Contrib. Mineral. Petrol., 73:323-340.

Aumento, L. K., Mitchell, W. S., and Fratta, M., 1976. Interaction between seawater and oceanic layer two as a function of time and depth, 1, field evidence. Can. Mineral., 14:269-290.

Bailey, S. W., 1980. Structures of layer silicates. In Brindley, G. W., and Brown, G. (Eds.), Crystal structures of clay minerals and their $\mathrm{X}$-ray identification. Mineralog. Soc. Monogr., 5:2-124.

Banks, H. H., 1972. Iron-rich saponite: Additional data on samples dredged from the Mid-Atlantic Ridge, $22^{\circ} \mathrm{N}$ latitude. Smithsonian Contrib. Earth Sci., 39, 9:39-42.

Baragar, W.R.A., Plant, A. G., Pringle, G. J., and Schau, M., 1977. Petrology and alteration of selected units of Mid-Atlantic Ridge basalts sampled from Sites 332 and 335, DSDP. Can. J. Earth Sci., 14:837-874.

Bass, M. N., 1976. Secondary minerals in oceanic basalts with special reference to Leg 34, Deep Sea Drilling Project. In Yeats, R. S., Hart, S. R., et al., Init. Repts. DSDP, 34: Washington (U.S. Govt. Printing Office), 393-432.

Bischoff, J. L., and Dickson, F. W., 1975. Seawater-basalt interaction at $200^{\circ} \mathrm{C}$ and 500 bars: Implications for origin of sea-floor heavy-metal deposits and regulation of seawater chemistry. Earth Planet. Sci. Letts., 25:385-397.

Böhlke, J. K., Honnorez, J., and Honnorez-Guerstein, B. M., 1980. Alteration of basalts from Site 396B, DSDP: Petrographic and mineralogic studies. Contrib. Mineral. Petrol., 73:341-364.

Buckley, H. A., Bevan, J. C., Brown, K. M., and Johnson, L. R., 1978. Glauconite and celadonite: Two separate mineral species. Min. Mag., 42:373-382.

Cann, J. R., 1970. Rb, $\mathrm{Sr}, \mathrm{Zr}$, and $\mathrm{Nb}$, in some ocean floor basaltic rocks. Earth Planet. Sci. Letts., 10:7-11.

1979. Metamorphism in the ocean crust. In Talwani, M., Harrison, C. G., and Hayes, D. E. (Eds.), Deep drilling results in the Atlantic Ocean: Ocean crust. American Geophysical Union, Washington, Geodynamics Project: Scientific Report, 48:230-238.

Crovisier, J. L., Fritz, B., Grambow, B., and Eberhart J. P., 1985. Dissolution of basaltic glass: Experiments and thermodynamic modelling. In Werme, L. (Ed.), Scientific basis for nuclear waste management. M.R.S. Symp. Proc., 50:273-280.

Crovisier, J. L., Honnorez, J., and Eberhart J. P., 1987. Dissolution of basaltic glass in seawater: Mechanism and rate. Geochim. Cosmochim. Acta, 51:2977-2990.

Detrick, R. S., Fox, P. J., Kastens, K., Ryan, W.B.F., and Karson, J., 1984. A Sea Beam survey of the Kane Fracture Zone and the adjacent Mid-Atlantic rift valley. Eos, 65;1106.

Detrick, R. S., Ryan, W.B.F., Mayer, L., Fox, P. J., Kong, L., Manchester, K., Kastens, K., Karson, J., and Pockalny, R., 1985. Mid-Atlantic Ridge/Kane Fracture Zone Final Site Survey Report: Prepared for Joint Oceanogr. Inst., Inc.

Donnelly, T. W., Pritchard, R. G., Emmermann, R., and Puchelt, H., 1979. The aging of oceanic crust: Synthesis of the mineralogical and chemical results of Deep Sea Drilling Project Legs 51 through 53. In Donnelly, T., Francheteau, J., Bryan, W., Robinson, P., Flower, M., Salisbury, M., et al., Init. Repts. DSDP, 51-53: Washington (U.S. Govt. Printing Office), 1563-1577.

Fodor, R. V., Berkley, J. L., Keil, K., Husler, J. W., Ma, M.-S., and Schmitt, R. A., 1980. Petrology of basalt drilled from the Galapagos Spreading Center, Deep Sea Drilling Project Leg 54. In Rosendahl, B. R., Hekinian, R., et al., Init. Repts. DSDP, 54: Washington (U. S. Govt. Printing Office), 737-749.

Gillis, K. M., 1986. Multistage alteration of the extrusive sequence, Troodos ophiolite, Cyprus [Ph.D. thesis]. Dalhousie University, Halifax, NS, Canada.

Gillis, K. M., and Robinson, P. T., 1988. Distribution of alteration zones in the upper oceanic crust. Geology, 16:262-266.
Hajash, A., 1975. Hydrothermal processes along mid-ocean ridges: An experimental investigation. Contrib. Mineral. Petrol., 53: 205-226.

Hekinian, R., and Hoffert, M., 1975. Rate of palagonitization and manganese coating on basaltic rocks from the rift valley in the Atlantic Ocean for $36^{\circ} 50^{\prime}$ N. Mar. Geol., 19:91-109.

Hekinian, R., Rosendahl, B. R., and Natland, J. H., 1980. Ocean crust geothermal processes: A perspective from the vantage of Leg 54 drilling. In Rosendahl, B. R., Hekinian, R., et al., Init. Repts. DSDP, 54: Washington (U.S. Govt. Printing Office), 395-422.

Hendricks, S. B., and Ross, C. S., 1941. The chemical composition and genesis of glauconite and celadonite. Am. Miner., 26:683-708.

Honnorez, J., 1981. The ageing of the oceanic crust at low temperature. In Emiliani, C. (Ed.), The Sea, Vol. 7: The oceanic lithosphere. New York, (Wiley), 525-587.

Honnorez, J., Laverne, C., Hubberten, H. W., Emmermann, R., and Muehlenbachs, K., 1983a. Alteration processes in layer 2 basalts from Deep Sea Drilling Project Hole 504B, Costa Rica Rift. In Cann, J. R., Langseth, M. G., Honnorez, J., Von Herzen, R. P., White, S. M., et al., Init. Repts. DSDP, 69: Washington (U.S. Govt. Printing Office), 509-546.

Honnorez, J., Karpoff, A.M., and Trauth-Badaut, D., 1983b. Sedimentology, mineralogy, and geochemistry of green clay samples from the Galapagos hydrothermal mounds, Holes 506, 506C, and 507D, Deep Sea Drilling Project Leg 70 (preliminary data). In Honnorez, J., Von Herzen, R.P., et al., Init. Repts. DSDP, 70: Washington (U.S. Govt. Printing Office), 211-224.

Karson, J. A., Brown, J. R., and Winters, A. T., 1986. Seafloor spreading in the MARK area. Eos, 67:1213.

Karson, J. A., Thompson, G., Humphris, S., Edmond, J., Bryan, W., Winters, A., Brown, J., Pockalny, R., Casey, J., Campbell, A., Klinkhammer, G., Palmer, M., Kinzler, R., and Sulanowska, M., in press. Along-axis variations in seafloor spreading in the MARK area. Nature.

Kempe, D.R.C., 1974. The petrology of the basalts, Leg 26. In Davies, T. A., Luyendyk, B. P., et al., Init. Repts. DSDP, 26: Washington (U.S. Govt. Printing Office), 465-504.

Kurnosov, V. B., Kholodkevich, I. V., Chubarov, V. M., and Shevchencko, A., Ya., 1983. Secondary minerals in basalt from the Costa Rica Rift, Holes 501 and 504B, Deep Sea Drilling Project Legs 68, 69, and 70. In Cann, J. R., Langseth, M. G., Honnorez, J., Von Herzen, R. P., White, S. M., et al., Init. Repts. DSDP, 69: Washington (U.S. Govt. Printing Office), 573-584.

Laverne, C., 1987. Les alterations des basaltes en domaine oceanique. Mineralogie, petrologie et geochemie d'un systeme hydrothermal: le puits 504B, Pacifique oriental. These de doctorat d'etat, Universite d'Aix Marseille III, 315 pp.

Laverne, C., and Vivier, G., 1983. Petrographical and chemical study of basement basalts from the Galapagos Spreading Center, Leg 70 . In Honnorez, J., Von Herzen, R. P., et al., Init. Repts. DSDP, 70: Washington (U.S. Govt. Printing Office), 375-389.

Lawrence, J. R., and Natland, J. H., 1981. Temperature of hydrothermal alteration in Deep Sea Drilling Project Hole 453, Western Mariana Trough. In Hussong, D. M., Uyeda S., et al., Init. Repts. DSDP, 60: Washington (U.S. Govt. Printing Office), 755-758.

Melson, W. G., and Thompson, G., 1973. Glassy abyssal basalt, Atlantic seafloor near St. Pauls rocks: Petrography and composition of secondary clay minerals. Geol. Soc. Am. Bull., 84:703-716.

Mevel, C., 1979. Mineralogy and chemistry of secondary phases in low temperature altered basalts from Deep Sea Drilling Project Legs 51, 52, and 53. In Donnelly, T., Francheteau, J., Bryan, W., Robinson, P., Flower, M., Salisbury, M., et al., Init. Repts. DSDP, 51-53: Washington (U.S. Govt. Printing Office), 1299-1317.

Natland, J. H., and Hekinian, R., 1981. Hydrothermal alteration of basalts and sediments at Deep Sea Drilling Project Site 456, Mariana Trough. In Hussong, D. M., Uyeda, S., et al., Init. Repts. DSDP, 60: Washington (U.S. Govt. Printing Office), 759-767.

Natland, J. H., and Mahoney, J. J., 1981. Alteration in igneous rocks at Deep Sea Drilling Project Sites 458 and 459, Mariana Fore-arc Region: Relationship to basement structure. In Hussong, D. M., Uyeda, S., et al., Init. Repts. DSDP., 60: Washington (U.S. Govt. Printing Office), 769-788. 
Pertsev, N. N., and Rusinov, V. L., 1979. Mineral assemblages and processes of alteration in basalts at Deep Sea Drilling Project Sites 417 and 418. In Donnelly, T., Francheteau, J., Bryan, W., Robinson, P., Flower, M., Salisbury, M., et al., Init. Repts. DSDP, 51-53: Washington (U.S. Govt. Printing Office), 1219-1242.

Pertsev, N. N., and Boronikhin, V. A., 1983. Alteration zones near veins in basalts from Deep Sea Drilling Project Sites 501/504 and 505, Costa Rica Rift. In Cann, J. R., Langseth, M. G., Honnorez, J., Von Herzen, R. P., White, S. M., et al., Init. Repts. DSDP, 69: Washington (U.S. Govt. Printing Office), 565-572.

Pritchard, R. G., 1979a. Alteration of oceanic basalts [Ph. D. thesis]. University of Newcastle upon Tyne, U.K. 1979b. Alteration of basalts from Deep Sea Drilling Project Legs 51, 52, and 53, Holes 417 A and 418A. In Donnelly, T., Francheteau, J., Bryan, W., Robinson, P., Flower, M., Salisbury, M., et al., Init. Repts DSDP, 51- 53: Washington (U.S. Govt. Printing Office), 1185-1199.

Pritchard, R. G., Cann, J. R., and Wood, D. A., 1979. Low-temperature alteration of oceanic basalts, DSDP Leg 49. In Luyendyk, B. P., Cann, J. R., et al., Init. Repts. DSDP, 49: Washington (U.S. Govt. Printing Office), 709-714.

Robinson, P. T., Flower, M.F.J., Schmincke, H. -U., and Ohnmacht, W., 1977. Low temperature alteration of oceanic basalts, Leg 37. In Aumento, F., Melson, W. G., et al., Init. Repts. DSDP, 37: Washington (U.S. Govt. Printing Office), 775-794.

Rona, P.A., 1984. Hydrothermal mineralization at sea-floor spreading centers. Earth Sci. Rev., 20:1-41.

Rusinov, V. L., Laputina, I. P., Muravitskaja, G. N., Zvjagin, B. B., and Gradusov, B. P., 1979. Clay minerals in basalts from Deep Sea Drilling Project Sites 417 and 418. In Donnelly, T., Francheteau, J., Bryan, W., Robinson, P., Flower, M., Salisbury, M., et al., Init. Repts. DSDP, 51-53: Washington (U.S. Govt. Printing Office), $1265-1271$.
Scarfe, C. M., and Smith, D.G.W., 1977. Secondary minerals in some basaltic rocks from DSDP Leg 37. Can. J. Earth Sci., 14:903-910.

Scheidegger, K. F., and Stakes, D. S., 1977. Mineralogy, chemistry, and crystallization sequence of clay minerals in altered tholeiitic basalts from the Peru Trench. Earth Planet. Sci. Letts., 36:413-422.

Schrader, E. L., and Stow, S. H., 1980. Geochemistry and mineralogy of fresh and altered basalts from the Galapagos Rift. In Rosendahl, B. R., Hekinian, R., et al., Init. Repts. DSDP, 54: Washington (U. S. Govt. Printing Office), 391-408.

Scott, R. B., and Hajash, A., 1976. Initial submarine alteration of basaltic pillow lavas. Am. J. Sci., 276:480-501.

Seyfried, W. E., Shanks, W. C., and Dibble, W. E., 1978. Clay mineral formation in DSDP Leg 34 basalt. Earth Planet. Sci. Letts., 41:265-276.

Shido, F., Miyashiro, A., and Ewing, M., 1974. Composition variation in pillow lavas from the Mid-Atlantic Ridge. Mar. Geol., 16:177-190.

Shipboard Scientific Party, 1988. Site 648. In Detrick, R., Honnorez, J., Bryan, W. B., Juteau, T., et al., Proc. ODP, Init. Repts., 106/109: College Station, TX (Ocean Drilling Program), 35-134.

Stakes, D. S., and Scheidegger, K. F., 1981. Temporal variations in secondary minerals from Nazca Plate basalts. Geol. Soc. Am. Bull., Nazca Plate Monograph.

Staudigel, H., Hart, S. R., and Richardson, S. H., 1981. Alteration of the oceanic crust: Processes and timing. Earth Planet. Sci. Letts., 52:311-327.

Thompson, G., 1973. A geochemical study of the low temperature interaction of seawater and oceanic igneous rocks. Eos, 54: 1015-1019.

Date of initial receipt: 31 October 1988

Date of acceptance: 20 April 1989

Ms 106/109B-140 